\title{
Host selection and ovipositor length in eight sympatric species of sculpins that deposit their eggs into tunicates or sponges
}

\section{Satoshi Awata, Haruka Sasaki, Tomohito Goto, Yasunori Koya, Hirohiko Takeshima, Aya Yamazaki, Hiroyuki Munehara}

\begin{tabular}{|c|c|}
\hline Citation & Marine Biology, 166(5); 59 \\
\hline Issue Date & 2019-04-06 \\
\hline Type & Journal Article \\
\hline Textversion & Author \\
\hline 概要 & $\begin{array}{l}\text { 研究グループは、他の生物に卵を預ける海産のカジカ科魚類 } 8 \text { 種について産卵宿主種 } \\
\text { (ホヤやカイメン) の特定に成功し、さらにはカジ科魚類が産卵管を宿主種の種類や大 } \\
\text { きさに忘じて進化させていることを世界で初めて発見しました。 } \\
\text { 今回の発見は、生態研究がほとんど進んでいない冷たい海域の動物の生態を知るうえ } \\
\text { で、非常に重要な成果と言えます。 } \\
\text { ‘ホヤに卵を預ける魚を初めて特定〜カジカ科魚類の産卵管と産卵行動は、産みつける宿主に応じて進化 } \\
\text { していた〜. 大阪市立大学. https://www.osaka-cu.ac.jp/ja/news/2019/190418. (参照 2019-04-18) }\end{array}$ \\
\hline Rights & $\begin{array}{l}\text { This is a post-peer-review, pre-copyedit version of an article published in Marine } \\
\text { Biology. The final authenticated version is available online at: } \\
\text { https://doi.org/10.1007/s00227-019-3506-4 . } \\
\text { See Springer Nature terms of use. } \\
\text { https://www.springer.com/gp/open-access/publication-policies/aam-terms-of-use . }\end{array}$ \\
\hline $\begin{array}{c}\text { Electronic } \\
\text { supplementary } \\
\text { material }\end{array}$ & $\begin{array}{l}\text { Electronic supplementary material is available online at: } \\
\text { https://doi.org/10.1007/s00227-019-3506-4. } \\
\text { カジカ科魚類のアサヒアナハゼがホヤに産卵する動画とアヤアナハゼがカイメンに産卵 } \\
\text { する動画 }\end{array}$ \\
\hline DOI & $10.1007 / \mathrm{s} 00227-019-3506-4$ \\
\hline
\end{tabular}

Self-Archiving by Author(s) Placed on: Osaka City University Repository

Awata, S., Sasaki, H., Goto, T. et al. Host selection and ovipositor length in eight sympatric species of sculpins that deposit their eggs into tunicates or sponges. Mar Biol (2019) 166: 59. doi:10.1007/s00227-019-3506-4 


\section{Original paper}

\section{Host selection and ovipositor length in eight sympatric species of sculpins that deposit their eggs into tunicates or sponges}

Satoshi Awata ${ }^{1,2} \cdot$ Haruka Sasaki $^{1}$ - Tomohito Goto ${ }^{1} \cdot$ Yasunori Koya $^{3} \cdot$ Hirohiko Takeshima $^{4,5} \cdot$ Aya Yamazaki $^{6} \cdot$ Hiroyuki Munehara $^{6}$

${ }^{1}$ Sado Marine Biological Station, Faculty of Science, Niigata University, Sado, Japan

${ }^{2}$ Laboratory of Animal Sociology, Graduate School of Science, Osaka City University, Osaka, Japan

${ }^{3}$ Department of Biology, Faculty of Education, Gifu University, Gifu, Japan

${ }^{4}$ Research Institute for Humanity and Nature, Kyoto, Japan

${ }^{5}$ Department of Marine Biology, School of Marine Science and Technology, Tokai University, Shizuoka, Japan

${ }^{6}$ Usujiri Fisheries Station, Field Science Center for Northern Biosphere, Hokkaido University, Hakodate, Japan

Short title: Host selection and ovipositor length in sculpins

Correspondence

Satoshi Awata

Laboratory of Animal Sociology, Graduate School of Science, Osaka City University, 3-3-138

Sugimoto, Sumiyoshi, Osaka 558-8585, Japan.

Tel.: +8166605 2607

e-mail: sa-awata@sci.osaka-cu.ac.jp

ORCID ID: 0000-0003-3254-7943 


\begin{abstract}
Interspecific interactions between parasites and hosts can influence the evolution of behavioural and morphological adaptations of both parasites and their hosts. There is, however, little empirical evidence available regarding the evolution of reproductive traits driven by these interactions. In this paper, we investigated host selection and ovipositor length in nine sympatric marine sculpins that oviposit into tunicates or sponges. Field and genetic studies have revealed host use for eight out of nine species of sculpins investigated here: five species of Pseudoblennius, two species of Furcina and one species of Vellitor. For one species studied (V. minutus), no egg masses could be found. Ovipositor length reflects morphology of host species utilised: six sculpin species had extremely long ovipositors allowing females to attach eggs to the deep atrium of solitary tunicates, whereas the two species that attached their eggs to the small space of atrial siphon of colonial tunicates and the spongocoel of sponges had short ovipositors. Ovipositor length varied between solitary-tunicate spawners and species with longer ovipositors selected larger tunicates. Since the ancestral form is non-parasitic, the ovipositor evolved as an adaptation to utilise sponges and tunicates as hosts. Sculpins found sympatrically may show host specificity to avoid interspecific competition for spawning niches and ovipositors may have evolved depending on the species and size of host invertebrates.
\end{abstract}

Keywords: ovipositor; sculpins; tunicates; sponges; marine fish; ostracophils. 


\section{Introduction}

Sexual selection, arising from interaction between sexes, has considerable influence on evolutionary adaptations in both sexes, for example, the morphological adaptation of reproductive traits (Andersson 1994; Birkhead and Møller 1998). However, as yet only a few studies have examined the evolution of reproductive traits in parasites through the interactions between parasites and hosts. In parasitic animals that utilise other organisms as oviposition hosts, female selection and oviposition success can strongly affect the survival of offspring and thereby parental fitness (e.g. Smith et al. 2001; Mills and Reynolds 2002, 2003; Kitamura 2005; Reichard et al. 2007), whereas hosts often incur costs due to egg deposition (e.g. Peden and Corbett 1973; Poltev and Mukhametov 2009; Reichard et al. 2006). Therefore, such interspecifically antagonistic interactions can influence the evolution of behavioural and morphological adaptations of either or both parasites and their hosts.

Some of the parasitic animals that inhabit aquatic environments preferentially deposit their eggs in live invertebrates (known as 'ostracophils': Balon 1975; Leung 2014). For example, bitterlings (Acheilognathinae) deposit their eggs in the gill chambers of freshwater mussels through their atrial siphon (e.g. Smith et al. 2004; Kitamura 2007), the Japanese tubesnout (Aulichthys japonicus) conceals their eggs in tunicates (Akagawa et al. 2008) and snailfishes (Liparidae) deposit eggs within the branchial chambers of crabs (e.g. Hunter 1969; Somerton and Donaldson 1998; Poltev and Mukhametov 2009; Gardner et al. 2016). All of these species display some degree of host specificity, and various degrees of adaptation of reproductive traits, for the deposition of their eggs inside invertebrates (reviewed in Leung 2014); for example, the extremely long ovipositors observed in both bitterlings (Smith et al. 2004; Kitamura 2007; Kitamura et al. 2012) and snailfishes (Hunter 1969). Similar adaptations of reproductive traits through interactions between parasites and hosts have been 
reported for various parasitic wasps including parasitoids that target free-living insects (Le Ralec et al. 1996), gall-makers (Ghara et al. 2011) and figs (Elias et al. 2018). These ostracophilous fishes and parasitic wasps have shown that sexual traits can be inter- and intraspecifically variable, due to interactions between parasites and hosts. However, empirical evidence regarding these variations in reproductive traits and host selection remain scarce.

Sculpins (Teleostei: Cottidae), which belong to the Cottoidea superfamily, are a large group of fish that have 70 genera and 282 species worldwide, and primarily inhabit boreal and cold temperate regions (Nelson et al. 2016). Although evidence is scarce, several species of Cottoidea are known to deposit their eggs inside alive invertebrates (reviewed in Abe and Munehara 2009; Munehara et al. 2011). For example, the little dragon sculpin Blepsias cirrhosus and the bigmouth sculpin Hemitripterus bolini utilise sponges as their spawning host (Munehara 1991; Busby et al. 2012). It has also been reported that four sculpin species in the genus Pseudoblennius that inhabit temperate waters seem to be ostracophils (Uchida 1932, 1979; Shinomiya and Ikemoto 1987; Okamura and Amaoka 1997; Nishida et al. 2008; Uryu 2011). According to these descriptive studies and to underwater photographs taken by divers, these species are all copulating species in which females deposit their eggs exclusively inside tunicates or sponges using their ovipositors (Shiogaki and Dotsu 1974; Shinomiya 1985; Abe and Munehara 2009; Nishida et al. 2008; Uryu 2011). In addition, during a preliminary study of marine sculpins in the nearshore reef of Sado Island, located in the Sea of Japan, it was found that there may be nine species of potentially ostracophilous sculpins (five species of Pseudoblennius, two species of Furcina and two species of Vellitor). They all develop ovipositors and occur sympatrically in shallow water of the island (Awata 2015, 2017). Therefore, these sculpins may be ideal for an examination of the evolution of interspecific variation in reproductive traits that are driven by interactions between parasites and hosts. However, no studies have demonstrated host selection and ovipositor morphology in sculpins, 
with the exception of one study that showed host tunicate selection by Pseudoblennius percoides (Nishida et al. 2008).

In this study, we investigated interspecific variation in host selection and ovipositor length in nine sympatric species of marine sculpins that deposit their eggs into tunicates or sponges on the coast of Sado Island, northern Japan. We hypothesise that species-specific host selection by sculpin females drives the evolution of ovipositor morphology. To confirm our hypothesis, we tested three predictions. Firstly, that the nine ostracophilous sculpin species would utilise different species and sizes of host tunicates or sponges to reduce interspecific competition for hosts (Reichard et al. 2007). This is because these sculpins co-occurred at the study sites. Secondly, that only ostracophilous sculpins, and not species that lay eggs on rock surfaces, would have elongated ovipositors. The morphological and molecular phylogeny of the sculpins suggests that ostracophilous sculpins have evolved from non-ostracophilous sculpins (Yabe 1985; Abe and Munehara 2009; Koya et al. 2011; Knope 2013). Therefore, the development of the ovipositor is likely related to such unique spawning behaviour. Finally, that ovipositor length would reflect the species and size of the hosts utilised.

\section{Materials and methods}

\section{Study sites}

Fieldwork using self-contained underwater breathing apparatus (SCUBA) was conducted on the coast of Sado Island in the Sea of Japan. The island is located about $45 \mathrm{~km}$ off the Japanese mainland coastal city of Niigata (Fig. 1a). The amplitude of the tides around the island is relatively low, ranging from only 0.2 to $0.3 \mathrm{~m}$. Four sites (Fig. 1b) were selected for fieldwork. All of the host invertebrates and ostracophilous sculpin species were abundant at the study sites, with the exception of V. minutus that was only found at Tassya (Awata 2017). 
The four study sites were located on rocky shores where seaweed grows abundantly.

\section{Fish study species}

There were nine species of potentially ostracophilous sculpins in the nearshore reef of Sado Island (Nakabo and Kai 2013; Awata 2015, 2017). Microhabitat preferences differ between species (Iwata 1983; Awata 2017), but all species occurred sympatrically in rocky shallow water ranging in depth from 1 to $20 \mathrm{~m}$. They are copulating species and their fertilisation mode is internal gametic association (IGA: Munehara et al. 1989), where fertilisation occurs only when eggs are released into the seawater (Shiogaki and Dotsu 1974; Kimura et al. 1987, 1988; Koya et al. 2015). Eggs that are released into seawater are spherical of 1.3-2.0 $\mathrm{mm}$ in diameter, demersal and adhesive, forming egg masses of up to 500 eggs (e.g. Kimura et al. 1987, 1988; Nishida et al. 2008). There are nine species in three genera, Furcina, Pseudoblennius and Vellitor, which form a closely related and monophyletic group (Yabe 1985; Munehara et al. 2011). The reproductive ecology is similar among species, but their body size and shape are notably different: Pseudoblennius sp. ("Kirin-anahaze" in Japanese, see Nakabo and Kai 2013) and Ps. percoides are large sized (130-170 mm in standard length, SL), Ps. cottoides, Ps. marmoratus and Ps. zonostigma are medium sized (80-100 mm SL) and F. ishikawae, F. osimae, V. centropomus and V. minutus are small sized sculpins (40-70 mm SL; Okamura and Amaoka 1997; Munehara et al. 2011; Nakabo and Kai 2013; Awata 2017).

\section{Fish collection and measurement of ovipositor length}

To examine the ovipositor length of the nine species of ostracophilous sculpins, adult females were captured using hand-nets while SCUBA diving during the spawning season, from late November to late April in 2014, 2015 and 2016, in depth of 2 to $15 \mathrm{~m}$ at all four study sites 
(Fig. 1b). The fish were transported in aerated coolers to the laboratory at the Sado Marine Biological Station (SMBS), Niigata University, Sado, Japan. Species identification of sculpins was based on that of Nakabo and Kai (2013). Fish were anaesthetised with a solution of MS222 or 2-phenoxyethanol buffered with seawater, and their SL (to $1 \mathrm{~mm}$ ) was measured using a scale. The ovipositor was induced to its maximum extrusion by gently pressing the belly of the fish between ventral fins and anus. The ovipositor was photographed alongside a scale, and ovipositor length (OL) was measured to the nearest $1 \mathrm{~mm}$ from the apex to the ventral edge of the ovipositor using image analysis software ImageJ 1.50i. A part of the right pectoral fin was clipped from each individual and preserved in $99 \%$ ethanol for genetic analysis. Of the 124 females analysed, 40 were released after the operation and 84 were used for other studies after sacrification under deep anaesthesia (taxonomy and sperm analyses: Awata 2015, 2017; histology: Koya et al. 2015).

To determine whether only ostracophilous sculpins have evolved elongated ovipositors, we compared the OL of ostracophilous sculpins and sculpin species that oviposit on the rock surface. We captured 13 females of four non-ostracophilous sculpin species (Alcichthys alcicornis, Bero elegans, Icelinus pietschi and Radulinopsis derjavini) using SCUBA at Usujiri (Fig. 1a), southern Hokkaido, Japan and at Kotoura, Sado Island, Japan, and measured their SL and OL.

\section{Collection of egg masses deposited in host invertebrates}

Egg masses deposited in the spongocoels of sponges and in the common atrial siphons of colonial tunicates were collected in April and May 2012, from March to May 2013 and from February to April 2014 at Kotoura and Kitakoura (Fig. 1b). Egg masses were externally visible, and therefore only whole colonies of sponges and colonial tunicates that contained egg masses were collected using scrapers. The colonies that contained eggs were distributed 
across rock wall habitats at depths of $1-12 \mathrm{~m}$. The sea water temperature was $9-14{ }^{\circ} \mathrm{C}$.

Because the egg masses deposited in the atria of solitary tunicates were rarely visible from outside, we haphazardly collected solitary tunicates $(n=1212)$ in December 2011, December 2012 and from December 2013 to May 2014 (approximately once a month) at Kitakoura, Mushizaki and Tassya (Fig. 1b). Of these, 1129 (93\%) tunicates were captured from the wall of Kitakoura Port at a depth of 0.5-4.0 m (Fig. 1c), where the wall was covered with in excess of a hundred thousand solitary tunicates. The remaining samples were collected at $8-18 \mathrm{~m}$ depth of off Kitakoura Port, at 8-30 $\mathrm{m}$ depth of Mushizaki and at 2-5 $\mathrm{m}$ of Tassya. The sea water temperature ranged from 9 to $16^{\circ} \mathrm{C}$ (the coldest being in February).

All tunicates, sponges and egg masses were transferred to the laboratory in aerated coolers. Sponges and colonial tunicates were cut from the osculum and common atrial siphon, respectively, to the spongocoel and common atrium. The length between the open top and the top of the egg mass was measured using a scale (defined as "egg mass position"). Solitary tunicates were photographed with a scale and their long diameter (LD) and short diameter (SD) were later measured using ImageJ $1.50 \mathrm{i}$ software. After being photographed, tunicates were carefully cut in half vertically using a kitchen knife, in order to avoid damaging the egg masses. When egg masses were found inside tunicates, opened tunicates were photographed again with a scale to measure the length from entrance of the atrial siphon to the nearest edge of the egg masses (also defined as "egg mass position"). It is natural to expect that utilisation of larger tunicates will require longer ovipositors, and thus egg mass position will be deeper when larger tunicates are used as hosts. The LD was used as an indicator of the body size of tunicates, given that their LD and SD are strongly correlated (Pearson's $r=0.92, p<0.0001$, $n=1212)$

Each egg mass removed from the host was counted and transferred to a box-shaped net cage $(12.5 \times 13.0 \times 8.0 \mathrm{~cm}$, mesh size: $0.5 \mathrm{~mm}$, s-5330, Sudo \& Company, Inc., Nagoya, 
Japan) that was fixed to the surface of a $90 \times 45 \times 45 \mathrm{~cm}$ tank at the SMBS. Each egg mass was separately incubated for $1-20$ days in the cage at $15^{\circ} \mathrm{C}$. Hatched larvae or late stage eggs (just before hatching) were preserved in $99 \%$ ethanol after being killed by an overdose of anaesthesia.

Note that egg masses of the Japanese tubesnout Aulichthys japonicas were also collected during this study, but the details of this will be published in a later paper.

\section{Genetic identification of parent species of egg masses}

To infer the parental species of the egg masses, 1-3 larvae per egg mass and fin-clip samples of nine potentially ostracophilous sculpins, with the addition of Jordania zonope as an outgroup, were chosen for use in genetic analyses. Fin-clip samples were obtained from 20112017 (Table S1, Supplementary Information). Whole genomic DNA was extracted from 148 adults and from 223 larvae (including late stage eggs) of 120 egg masses, using a Gentra Puregene Tissue Kit (Qiagen, Hilden, Germany). Samples were PCR amplified for the mitochondrial cytochrome $b$ gene (cytb): GLUDG-L: 5'-YGACTTGAARAACCAYCGTTG3' and CB3-H: 5'-GGCAAATAGGAARTATCATTC-3' (Palumbi 1996; Knope 2013). PCR amplifications were performed at a $15 \mu \mathrm{L}$ volume using $7.5 \mu \mathrm{L}$ of $2 \times$ Go Taq Green Master Mix (Promega, WI, USA), $0.6 \mu \mathrm{L}(5 \mu \mathrm{M})$ of each primer, $1.5 \mu \mathrm{L}$ ca. $50 \mathrm{ng} / \mu \mathrm{L}$ of template DNA and $4.8 \mu \mathrm{L}$ of nuclease free water. PCR thermal cycling was performed using the following protocol for $c y t b: 2 \mathrm{~min}$ of initial denaturation at $95^{\circ} \mathrm{C}$, followed by 35 cycles of $94{ }^{\circ} \mathrm{C}$ for $30 \mathrm{sec}, 50{ }^{\circ} \mathrm{C}$ for $30 \mathrm{sec}$ and $72{ }^{\circ} \mathrm{C}$ for $1 \mathrm{~min}$. PCR amplifications were successful except for some Ps. cottoides and Ps. zonostigma and many of the egg masses, for which sequences corresponding to the primers were permutated. Therefore, these samples were PCR amplified using another primer set for $c y t b$ : H15915: 5'-CAACGATCTCCGGTTT-3' and L14724: 5'-GTGACTTGAAAAACCA-3' (Schmidt and Gold 1993). The 800 bp sequences 
amplified by this primer set overlapped with those amplified by the former primer set. PCR products were electrophoresed on $1.5 \%$ agarose gel stained with GelRed ${ }^{\mathrm{TM}}$ (Biotium, Inc., CA, USA). Positive amplicons (evidenced by a clear single band of the correct size) were enzymatically cleaned with illustra ${ }^{\mathrm{TM}} \operatorname{ExoStar}^{\mathrm{TM}}$ (GE Healthcare UK Limited, Little Chalfont, Buckinghamshire, UK). Double stranded PCR products were sequenced directly with the same primers used for the PCR amplifications at Macrogen Japan Corp. (Kyoto, Japan). All sequences were aligned using the ClustalW algorithm implemented in MEGA ver. 7.0.14. (Kumar et al. 2016).

The phylogenetic relationships of nine potential parental species $(n=146)$ and Jordania zonope ( $n=2$, as the root for the tree) were reconstructed using 800 bp cytb sequences with MEGA ver. 7.0.14, and the Maximum Likelihood method was employed using the Tamura Nei model settings (Tamura and Nei 1993) and 1000 bootstrap replicates. After assessing the usefulness of the sequences for species identification (Fig. S1, Supplementary Information; all these sequences available on GenBank, Table S1), the parental species of egg masses were estimated using the reconstructed phylogeny of the parental species and egg masses. Of 223 eggs analysed, 205 were identified using 800 bp cytb sequences, and 18 were identified using $628 \mathrm{bp}$, due to the low quality of the sequencing data.

\section{Data analyses}

Statistical analyses were performed using SPSS ver. 23.0 (IBM Corp., Armonk, NY, USA). Data were analysed using parametric statistics throughout. All reported $p$-values were two tailed, and results were considered statistically significant at $p$-values of $<0.05$. As we did not obtain all data from all sponges and tunicates, sample size varied between analyses. To determine whether the relative OL differed between ostracophilous and non-ostracophilous sculpins, we used an analysis of covariance (ANCOVA) with log-transformed OL as the 
dependent variable and deposition site (sponge, colonial tunicate, solitary tunicate and rock surface) as the independent variable and log-transformed SL as the covariate, including their interaction (full model). If the interaction term (deposition site $\times \log$ SL) was not statistically significant, then a reduced model was constructed by reducing the interaction term.

\section{Results}

\section{Egg masses deposited in sponges and colonial tunicates}

Nine egg masses were obtained from sponges (Demospongiae) of nine colonies. Since each colony was small and formed mostly only one spongocoel, multiple egg masses were not found in sponges sampled (Fig. 2a). In contrast, the colony size and shape of colonial tunicates (Didemnidae) were variable, ranging from 20 to $100 \mathrm{~mm}$ in maximum width, each of which had 1-38 exhalant siphons and contained 1-5 sculpin egg masses at similar or different developmental stages (Fig. 2b, c). In total, 34 egg masses were obtained from the colonial tunicates of 22 colonies.

\section{Egg masses deposited in solitary tunicates}

Of 1212 solitary tunicates collected, seven species were identified. The most commonly occurring was Halocynthia ritteri $(55.9 \%, n=678)$, followed by Polycarpa cryptocarpa kroboja $(25.3 \%, n=307)$, Cnemidocarpa irene $(11.6 \%, n=141)$, Pyura sacciformis $(3.5 \%$, $n=42)$, Microcosmus hartmeyeri $(2.0 \%, n=24)$, H. roretzi $(1.6 \%, n=19)$ and Herdmania japonica $(0.1 \%, n=1)$. Although a considerable number of tunicates were collected, sculpins only utilised three species (Fig. $2 \mathrm{~d}-\mathrm{h}$ ). The two largest and the smallest species of tunicates were not used by the sculpins (Fig. 3). The second most abundant tunicate Po. c. kroboja was never used by sculpins, although notably overlapped in size with the most abundant and most 
frequently used tunicate $H$. ritteri (Fig. 3).

Of the 89 sculpin egg masses collected, > $90 \%$ were found in $H$. ritteri and the remainder were found in Py. sacciformis and H. roretzi (Fig. 2f-h; Fig. 3). Although the abundance of $H$. ritteri was more than 16 times greater than that of Py. sacciformis at the study sites, the proportion of parasitized tunicates was equal ( $n_{\text {with eggs }} / n_{\text {without eggs }}=75 / 593$ for H. ritteri; 6/30 for Py. sacciformis: Fisher's exact test, $p=0.29)$. Note that sculpin eggs were only found in the atria of tunicates, indicating that the ovipositors were inserted through the atrial siphon of the tunicates.

\section{Parental species of egg mass}

The reconstructed phylogenetic relationships of the potentially parental species and 120 egg masses showed that sponges were utilised by Ps. marmoratus ( $n=4$ egg masses, Fig. $2 \mathrm{a})$ and V. centropomus $(n=4)$ as spawning hosts (details in Table S2). All 26 egg masses deposited in colonial tunicates were assigned to V. centropomus (Fig. 2b). Solitary tunicates were used by six sculpin species (Table 1; Fig. 2d-h; details in Table S3): egg masses of Ps. cottoides were the most frequent ( $n=52$ egg masses), followed by those of Ps. zonostigma $(n=13)$, Pseudoblennius sp. "Kirin-anahaze" $(n=9)$, Ps. percoides $(n=8)$, F. osimae $(n=3)$ and F. ishikawae $(n=1)$. Five of six species mainly employed H. ritteri as their hosts (Table 1; Fig. 2f). Pseudoblennius cottoides and Ps. percoides also utilised Py. sacciformis. Egg masses deposited in H. roretzi were identified as belonging to Pseudoblennius sp. "Kirin-anahaze" (Fig. 2g). Furcina osimae only utilised Py. sacciformis as the tunicate host (Fig. 2h). No egg masses were genetically assigned to V. minutus and so further analyses excluded this species.

\section{Egg mass position in different hosts}

Since egg masses were visible from the outside of sponges and colonial tunicates, but were 
not for solitary tunicates, the egg mass position would be expected to differ between the hosts. As expected, the egg masses were deposited significantly deeper in solitary tunicates $(16.44 \pm$ $6.39 \mathrm{~mm}, n=73)$ than in sponges $(2.70 \pm 1.69 \mathrm{~mm}, n=6)$ and colonial tunicates $(2.02 \pm 1.79$ mm, $n=11$ ) (one-way ANOVA, $F_{2,87}=40.46, p<0.0001$; Tukey's HSD, $p<0.0001$ for both). The egg mass position did not differ between sponges and colonial tunicates (Tukey's HSD, $p=0.97)$. This indicates that ovipositor length likely differs between sculpin species using solitary tunicates and those using sponges and colonial tunicates.

\section{Comparison of ovipositor length between fish using different deposition sites}

An ANCOVA analysis showed that the interaction between deposition site and log SL did not have a significant effect on $\log$ OL (full model, $F_{3,129}=2.09, p=0.11$ ), and overall, larger species/individuals had longer ovipositors (reduced model, $F_{1,132}=176.77, p<0.0001$; Fig. 4a). As predicted, the relative OL was significantly related to deposition site (reduced model, $F_{3,132}=557.23, p<0.0001 ;$ Fig. $\left.4 \mathrm{a}\right)$. The relative OL of the ostracophilous sculpins was significantly longer than that of the non-ostracophilous sculpins (Fig. 4b-e). Moreover, the sculpin species that use solitary tunicates as hosts had much longer OLs (ca. $20 \%$ of SL) than that of those using colonial tunicates and sponges. Although the relative OL differed significantly between V. centropomus (ca. $5 \%$ of SL) and Ps. marmoratus (ca. $3 \%$ of SL), the absolute OL did not differ between them ( $t$-test, $t=0.99, p=0.33$; Fig. 4a-c).

\section{Ovipositor length and the size of solitary tunicates used by sculpins}

The body size of the six parental species that utilised solitary tunicates as hosts differed significantly among species (one-way ANOVA, $F_{5,89}=166.84, p<0.0001$; Fig. 5a). Female Pseudoblennius sp. "Kirin-anahaze" were the largest, and two species in the Furcina genus were the smallest of all six species. Overall, larger species had longer ovipositors $\left(F_{5,89}=\right.$ 
28.05, $p<0.0001$; Fig. 5b), but the OL of Ps. percoides was significantly shorter than that of Ps. cottoides despite its larger body size (also see Fig. 4a).

As expected, egg mass position was deeper when larger tunicates were used as hosts (Pearson's $r=0.49, p<0.0001, n=72$ ). The LD of tunicates used as hosts and the egg mass position were significantly different among sculpin species (LD: Fig. 5c; one-way ANOVA, $F_{4,79}=8.81 p<0.0001$; egg mass position: Fig. $\left.5 \mathrm{~d} ; F_{4,68}=7.05, p<0.0001\right)$. Consistent with the expectation that utilisation of larger tunicates will require longer ovipositors, the LD of tunicates used as hosts and the egg mass position were closely related to the sculpin OL (Fig 5); Pseudoblennius sp. “Kirin-anahaze", Ps. cottoides and Ps. zonostigma that have longer ovipositors spawned in a deeper position in larger tunicates, and the genus Furcina with a smaller body size and a shorter ovipositor consequently utilised smaller tunicates. Pseudoblennius percoides, which has a larger body size but a shorter ovipositor, selected smaller tunicates as spawning hosts.

Pseudoblennius sp. "Kirin-anahaze", Ps. cottoides and Ps. zonostigma used similarsized H. ritteri tunicates as hosts (Fig. 5c), indicating severe competitions for hosts among the three species. However, if host $H$. ritteri is abundant and sculpins use the most common size of tunicates, competition for hosts would be weakened. Indeed, H. ritteri was used by only $11 \%$ of all individuals (Fig. 3d). Additionally, the average and variance of host size were similar between unused $H$. ritteri $(84.20 \mathrm{LD} \pm 20.31, n=595)$ and that used by Pseudoblennius sp. "Kirin-anahaze" $(92.84 \mathrm{LD} \pm 10.37, n=7, t$-test, $t=1.12, p=0.26 ; F$ test to compare two variances, $F=3.84, p=0.09)$, Ps. cottoides $(87.16 \mathrm{LD} \pm 18.38, n=46, t=$ $0.96, p=0.34 ; F=1.22, p=0.41$ ) or Ps. zonostigma (although slightly larger tunicates were used: $99.12 \mathrm{LD} \pm 17.37, n=11, t=2.42, p=0.02 ; F=1.37, p=0.61)$. These show that these three sculpins used the most common size of H. ritteri (Fig. 3d). 


\section{Discussion}

\section{Host specificity}

In this study, we identified oviposition hosts in eight out of the nine ostracophilous sculpins examined. While a number of researchers and divers have observed spawning behaviours of some of these sculpins, such as Ps. marmoratus, Ps. percoides and Ps. zonostigma (Shinomiya 1985; Okamura and Amaoka 1997; Abe and Munehara 2009; Uryu 2011), so far only one study has reported host tunicate selection by Ps. percoides (Nishida et al. 2008). Thus, to our knowledge, this is the first study to confirm the host species used by these eight sculpin species, including Ps. percoides. There are three patterns of host use by sculpins, such as species that mainly use colonial tunicates, those that only use sponges and those that only use solitary tunicates for oviposition. This result mostly confirms our first prediction, that ostracophilous sculpins would show host specificity. However, as found in ostracophilous bitterlings (Reichard et al. 2007), sculpins also showed variation in their level of specificity. Pseudoblennius marmoratus oviposited only in the spongocoel of sponges, but $V$. centropomus utilised colonial tunicates and sponges for oviposition. Eggs of six sculpin species were found in solitary tunicates, but three of these fishes used only a single tunicate species and the others used two tunicate species.

Egg mass numbers for each sculpin species collected in this study mostly corresponded to the abundance of parental species at the study sites (see Fig. 4, Table 1). Although we captured most tunicates on the wall of Kitakoura Port, the consistency of appearance frequencies between eggs and parental species implies that the six sculpin species do not avoid the artificial habitat for spawning. Since eggs of V. minutus were not found and only one egg mass of F. ishikawae was collected, further field sampling including different sites and seasons are needed to clarify their host use. 
Sponges are only distantly related to colonial tunicates (e.g. Dunn et al. 2014). Their body structures are therefore notably different. However, they share morphological similarities: both have myriad brachial apertures and shared, common cloacal apertures. These similarities, especially the common structure of the cloacal apertures, may allow female $V$. centropomus to utilise both colonial tunicates and sponges as hosts. To our knowledge, it is unlikely that any other fishes utilise such distantly related taxa. Pseudoblennius marmoratus only oviposit in sponges, which is consistent with previous underwater observations (Uryu 2011). It remains unclear whether Ps. marmoratus also utilises colonial tunicates. To confirm this, more information on its spawning behaviour in the field needs to be gathered. These two sculpin species have short and similarly sized ovipositors, suggesting that they are specialised in ovipositing in colonial tunicates and sponges.

We found that sculpins used only three out of seven species of solitary tunicates as hosts, even though many species of tunicates co-occurred at the study sites. There are three possibilities to explain sculpin host selection: 1) the size of the tunicates, 2) the internal structure of the tunicates and 3) chemical substances in the atria of the tunicates. First, sculpins may select for tunicates of optimal size. Solitary tunicate spawners have developed long ovipositors, which may allow the placement of their eggs in the atrium of tunicates via the atrial siphon. The elongation of the ovipositor is limited by the cost associated with growing and maintaining a long ovipositor. Sculpin females did not use the large tunicates $M$. hartmeyeri and Herdmania japonica, probably due to the excessively long distance from the entrance of atrial siphon to the atrium of the tunicate. In contrast, the small atrium and narrow entrance of the atrial siphon of the smallest tunicate, C. irene, was too small to allow sculpins to use them as hosts.

Second, the internal structure of tunicates may be related to host selection by sculpins. Our data showed that the size range of unused tunicate Po. c. kroboja greatly 
overlapped with that of the commonly used tunicate H. ritteri. The unused Po. c. kroboja tunicates are more compressed compared with the H. ritteri tunicates (Awata S. pers. obs.), suggesting that sculpins do not utilise Po. c. kroboja due to the small inner space of their atria. Finally, substances in the atria of tunicates might also affect host use by female sculpins. A number of tunicates produce chemical defences, such as high sulfuric acid and high vanadium content, which may reduce their predation risks (e.g. Stoecker 1980; Paul and Puglisi 2004; Paul et al. 2006). Polycarpa cryptocarpa kroboja has a uniquely strong smell (Awata S. pers. obs.) compared to the other tunicate species dissected. Although the chemical components responsible for this smell were not identified, they may have adverse effects on the fish eggs. Our aquarium experiments have demonstrated that when Ps. cottoides females with ripe eggs were allowed to choose $H$. ritteri and Po. c. kroboja of the similar size, they spent more time inspecting $H$. ritteri, and eggs were deposited only in $H$. ritteri (Awata S, Igarashi N, unpub. data). This indicates that the female sculpins likely discriminate between H. ritteri and Po. c. kroboja prior to spawning, and clearly prefer the former over the latter as oviposition hosts. It remains to be experimentally determined which combinations of these proximate factors such as tunicate size, structure and chemical substances affect host selection by female sculpins.

\section{Ovipositor length}

In accordance with our second prediction, only ostracophilous sculpins had elongated ovipositors, while non-ostracophilous sculpins lacked this feature. Since non-ostracophilous sculpins have been suggested to be the ancestral state (Yabe 1985; Koya et al. 2011; Munehara et al. 2011; Knope 2013), we can conclude that the elongated ovipositor has evolved as an adaptation to the ostracophilous reproduction strategy. The ovipositor in species using solitary tunicates as hosts was much longer than that in species using colonial tunicates and sponges. The position of eggs oviposited in colonial tunicates and sponges were as short 
as they were observed to be from the outside, and perfectly matched the short ovipositor length of V. centropomus and Ps. marmoratus. In contrast, sculpins that oviposited in solitary tunicates had extremely long ovipositors, which in turn matched the distance from the entrance of the atrial siphon to the edge of the egg masses. These results are consistent with the third prediction, that ovipositor length would reflect the species and size of hosts utilised.

Both the branchial and atrial siphons of solitary tunicates close immediately by ejecting the water from their body when they detect external stimuli such as vibrations in the water. In contrast, sponges and colonial tunicates shrink a little after the detection of such stimuli (Awata S. pers. obs.). In response to such host behaviour, female sculpins that use solitary tunicates as hosts insert their ovipositors rapidly into the atrium (Movie S1, S2, Supplementary Information). In contrast, species that use sponges as hosts oviposit slowly (Movie S3). Based on these observations, we suggest that spawning behaviour and ovipositor length may have adapted to suit the different hosts.

\section{Competition among sculpin species over hosts}

In this study, six species of sculpins were determined to use solitary tunicates as hosts.

Furcina osimae only used the tunicate Py. sacciformis as a spawning host, but the other five species mainly deposited their eggs into $H$. ritteri. This suggests these five species did not prefer specific host tunicates. However, their host use may be also related to the size and species of the host tunicates. Indeed, two smallest species of genus Furcina, which have shorter ovipositors, used smaller tunicates; the largest Pseudoblennius sp. "Kirin-anahaze", which has longer ovipositors, spawned in larger tunicates. In contrast, the ovipositor of Ps. percoides was shorter than that of Ps. cottoides, despite its larger body, and matches the size of the host tunicates. Medium-sized sculpins such as Ps. cottoides and Ps. zonostigma had medium-sized ovipositors but used larger tunicates as hosts. Thus, as expected from our first 
prediction, sculpins likely choose different sized hosts that fit their ovipositor size, probably to reduce interspecific competition for hosts (Reichard et al. 2007).

However, three sculpins (Pseudoblennius sp. "Kirin-anahaze", Ps. cottoides and Ps. zonostigma) showed similar host choice in terms of species and size, indicating that interspecific competition for hosts may be unavoidable (Kitamura 2007; Reichard et al. 2007). Previous studies have shown that host utilisation by female bitterlings may be determined by host availability, as well as by host preference and interspecific competition among bitterlings (Kitamura 2007; Reichard et al. 2007). In this study, the most abundant host, H. ritteri, was used by only $11 \%$ of all individuals. Furthermore, these three sculpins used the most common size of tunicates (65-105 mm in LD of host $H$. ritteri; see Fig. 3d), although Ps. zonostigma oviposited into somewhat larger tunicates. Therefore, their host preferences are strongly related to host availability, and the ovipositor length of those three species may have been shaped by the size of the most abundantly available tunicates. Further experimental studies are needed to identify the "real" host size and species preference by controlling for host availability and interspecific competition among ostracophilous sculpins (Reichard et al. 2007). Since most Pseudoblennius species are piscivores (Okamura and Amaoka 1997; Uryu 2011), it would be necessary to take the risk of predation of smaller species and individuals by larger ones into account when determining interspecific competition at the spawning sites.

\section{Costs and benefits for ostracophilous sculpins}

There are at least three potential benefits for female sculpins that use tunicates and sponges as oviposition hosts. First, the hosts may provide suitable environments for embryonic development (Hunter 1969; Munehara 1991; Spence and Smith 2013). Both tunicates and sponges are filter feeders that draw water and food particles through incurrent siphon or canals and excrete the filtered water through atria and excurrent siphons, or through 
spongocoels and oscula. Parental care by fishes that exclusively exhibit care for their eggs mainly consists of fanning and mouthing, which are assumed to increase the oxygen supply and to help to remove dead eggs and dust particles (e.g. Keenleyside 1991). Since filtered water constantly flows through the atria of tunicates and the spongocoels of sponges where the eggs are deposited, the hosts may inadvertently serve a similar function to fanning and mouthing for the eggs. Furthermore, sponges may provide another benefit to egg development in sculpins. Many studies have reported that sponges contain compounds with antibacterial and antifungal properties (e.g. reviewed in Mehbub et al. 2014). Considering the absence of dead eggs in sponges, the antibacterial and antifungal activities of sponges may increase the survival rate of sculpin eggs. Although dead, un-decayed eggs of the little dragon sculpin $B$. cirrhosus have been found to be present in sponge tissues (Munehara 1991), such eggs were not found in our study, perhaps due to the difference in embryonic periods $(<1$ month in our study species and $>8$ months in B. cirrhosis; Munehara 1991). Rose bitterling embryos developing on the gills of freshwater mussels are known to gain nutrients and oxygen from the water taken in by the mussels (Spence and Smith 2013). However, this may not be the case in sculpins, because their eggs are placed where few or no nutrients may be available due to the filtered water, and larvae are likely to leave their host soon after hatching since they are capable of active swimming (Kimura et al. 1987, 1988; Awata S. pers. obs.).

Second, eggs are likely protected from predators by being hidden inside the hosts (Hunter 1969; Munehara 1991). Since eggs are completely hidden in solitary tunicates that have rigid bodies, predation avoidance may be highly effective. Furthermore, many species of sponges are chemically defended from predation by marine animals, such as fishes, sea urchins, sea stars and hermit crabs (e.g. reviewed in Paul and Puglisi 2004; Paul et al. 2006). Thus, oviposition in sponges may also be effective for predation avoidance due to their chemical defences. Third, females are not required to provide parental care, which may allow 
them to utilise their energy reserves for further reproduction, such as increasing egg numbers and size.

However, it is costly to be ostracophilous. First, the development of elongated ovipositors and unique spawning behaviour are essential. Second, during the spawning season, sculpin females must seek out suitable, limited oviposition hosts, which might increase the probability of predation and consume energy reserves. Despite such costs, the benefits for female sculpins specialising in the use of tunicates and sponges outweigh the costs, which may be the evolutionary forces that produce and maintain the unique spawning behaviours observed in sculpins. This also may be the case for other ostracophilous fishes such as bitterlings, snailfishes and Japanese tubesnouts (Leung 2014).

\section{Costs and benefits for hosts}

In contrast to the potential benefits obtained by the sculpins, it is unlikely that sculpins and their eggs have positive impacts on the host tunicates and sponges. Conversely, the eggs deposited by sculpins may adversely affect their hosts. One possible cost for the hosts harbouring sculpin egg masses is the reduction of sea water exchange, as observed in mussels (Smith et al. 2001; Mills and Reynolds 2002, 2003; Kitamura 2005). In many cases, one egg mass was found in a solitary tunicate, and occupied only a small space in the atrium. However, the eggs, especially those oviposited by larger sculpin species such as Pseudoblennius sp. "Kirin-anahaze", sometimes entirely fill up the tunicate atrium due to their large clutch size (see Table S3). In this case, the hosts cannot effectively exchange seawater and consequently might incur some costs such as lowered growth and survival from the overload of fish eggs. Such an overload of fish eggs has been reported for the snailfishcrab system, where the load of the egg masses in the gill cavity of crabs deposited by snail fish caused severe damage to their gills (Love and Shirley 1993; Somerton and Donaldson 
1998; Poltev and Mukhametov 2009). Spence and Smith (2013) have also found that some host mussels with many bitterling eggs died, probably due to severe competition for oxygen between the host mussels and bitterling embryos. Since sculpin eggs are not oviposited on the gills of tunicates through the incurrent siphon, sculpin eggs unlikely do cause severe damage to the respiratory system of sponges and tunicates. Experimental work is needed to ascertain the cost to the hosts of sculpin eggs.

\section{Conclusions}

In summary, we have shown host selection and variation of ovipositor length in eight out of nine sympatric marine sculpins found off the shore of an island in the Sea of Japan. To date, ostracophilous behaviour has only been described for a small number of fish species, and therefore only limited data on the behavioural and morphological adaptations of parasites and hosts are available, with the exception of the bitterlings. A more recent study, however, has found evidence of ostracophilous behaviour in the tubenose poacher Pallasina barbata (Momota and Munehara 2017). Sculpins and tubenose poachers are different fish groups from other ostracophilous fishes (Leung 2014), suggesting that ostracophilous reproductive strategy has likely evolved in parallel across different taxa (Leung 2014). This study has shown the morphological adaptations of sculpin females at the interspecific level. However, ongoing research will need to examine the intraspecific variation in ovipositor size and morphology, depending on the host species used and their size. Studying ostracophils at the population level might be particularly worthwhile to identify the (co-)evolution of behavioural and morphological adaptations of parasites and their hosts.

\section{Ethical statement}


The research reported in this study was carried out in accordance with Animal Care and Use Committees at Niigata University and Osaka City University. All of the procedures described above meet the ABS/ASAB guidelines for the ethical treatment of animals. Research permission was obtained from Fisheries Cooperative Association of Sado, Japan.

\section{Acknowledgements}

We thank Teruaki Nishikawa and Yuji Ise for help with the classification of tunicates and sponges. We are also grateful to Mitsuo Homma (Diving Service F. Wave), Ryo Honma (Sado

Diving Centre), Yoshihisa Sato (Senkakuwan Ageshima Aquarium), Akihiro Yamada, Hiromitsu Takashima (Ogi Diving Centre), Tadashi Shoji (Diving Service S. World), Sadogashima SCUBA Diving Association and Kitakoura Recreational Fishing Cooperative for support in the field. We would like to thank Tomonobu Uryu for creating videos for us and Editage (http:// www.editage.jp) for English language editing. The anonymous reviewers provided helpful comments on the manuscript. The project was financially supported in part by JSPS KAKENHI Grant Numbers JP24770016 and JP16H04841 to S.A., JP26450259 to Y.K. and JP25304011 to H.M. and by the Sasaki Environment Technology Foundation (H26) to S.A.

\section{References}

Akagawa I, Hara M, Iwamoto T (2008) Egg concealment in tunicates by females of the Japanese tubesnout, Aulichthys japonicus (Gasterosteiformes), and its subsequent copulation. Ichthyol Res 55:85-89

Abe T, Munehara H (2009) Adaptation and evolution of reproductive mode in copulating cottoid species. In: Jamieson BGM (Ed.) Reproductive Biology and Phylogeny of Fishes (Agnathans and Bony Fishes). Science Publishers, Enfield, pp 221-246 Andersson M (1994) Sexual selection. Princeton Univ. Press, Princeton Awata S (2015) Diversity and evolution of reproductive strategies in marine sculpins. 
Aquabiol 37:614-621

Awata S (2017) Taxonomic and ecological notes on marine sculpins on the coast of Sado Island in the Sea of Japan. Nat Hist Sado Isl 5:9-20

Balon EK (1975) Reproductive guilds of fishes - proposal and definition. J Fish Res Board Can 32:821-864

Birkhead TR, Møller AP (1998) Sperm competition and sexual selection. Academic Press, London

Busby MS, Blood DM, Fleischer AJ, Nichol DG (2012) Egg deposition and development of eggs and larvae of bigmouth sculpin (Hemitripterus bolini). Northwest Nat 93:1-16

Dunn CW, Giribet G, Edgecombe GD, Hejnol A (2014) Animal phylogeny and its evolutionary implications. Annu Rev Ecol Evol Syst 45:371-395

Elias LG, Kjellberg F, Farache FHA, Almeida EAB, Rasplus J-Y, Cruaud A, Peng Y-Q, Yang D-R, Pereira RAS (2018) Ovipositor morphology correlates with life history evolution in agaonid fig wasps. Acta Oecol 90:109-116

Gardner JR, Orr JW, Stevenson DE, Spies I, Somerton DA (2016) Reproductive parasitism between distant phyla: molecular identification of snailfish (Liparidae) egg masses in the gill cavities of king crabs (Lithodidae). Copeia 104:645-657

Ghara M, Kundanati L, Borges RM (2011) Nature's Swiss Army knives: ovipositor structure mirrors ecology in a multitrophic fig wasp community. PLoS ONE 6:e23642

Hunter CJ (1969) Confirmation of symbiotic relationship between liparid fishes (Careproctus spp.) and male king crab (Paralithodes camtschatica). Pac Sci 23:546-547

Iwata A (1983) A revision of the cottid fish genus Vellitor. Jap J Ichthyol 30:1-9

Keenleyside MHA (1991) Parental care. In: Keenleyside MHA (Ed.) Cichlid fishes: behaviour, ecology and evolution. Chapman and Hall, London, pp 191-208

Kimura S, Tsumoto K, Mori K (1987) Development of eggs, larvae and juveniles of the cottid fish, Pseudoblennius cottoides, reared in the laboratory. Jap J Ichthyol 34: 346-350

Kimura S, Tsumoto K, Mori K (1988) Development of the cottid fish, Pseudoblennius percoides, reared in the laboratory, with brief descriptions of juvenile P. marmoratus and P. zonostigma. Jap J Ichthyol 35:19-24

Kitamura J (2005) Factors affecting seasonal mortality of rosy bitterling (Rhodeus ocellatus kurumeus) embryos on the gills of their host mussel. Popul Ecol 47:41-51

Kitamura J (2007) Reproductive ecology and host utilization of four sympatric bitterling (Acheilognathinae, Cyprinidae) in a lowland reach of the Harai River in Mie, Japan. Environ Biol Fish 78:37-55

Kitamura J, Nagata N, Nakajima J, Sota T (2012) Divergence of ovipositor length and egg shape in a brood parasitic bitterling fish through the use of different mussel hosts. J Evol Biol 25:566-573

Knope ML (2013) Phylogenetics of the marine sculpins (Teleostei: Cottidae) of the North American Pacific Coast. Mol Phylogenet Evol 66:341-349

Koya Y, Hayakawa Y, Markevich A, Munehara H (2011) Comparative studies of testicular 
structure and sperm morphology among copulatory and non-copulatory sculpins (Cottidae: Scorpaeniformes: Teleostei). Ichthyol Res 58:109-125

Koya Y, Mitsuhashi N, Awata S, Ito T, Munehara H (2015) Identification of the reproductive mode for internal gamete association in Vellitor centropomus (Cottidae): gonadal histological analysis. Japan J Ichthyol 62:121-131

Kumar S, Stecher G, Tamura K (2016) MEGA7: Molecular Evolutionary Genetics Analysis version 7.0 for bigger datasets. Mol Biol Evol 33:1870-1874

Le Ralec A, Rabasse JM, Wajnberg E (1996) Comparative morphology of the ovipositor of some parasitic Hymenoptera in relation to characteristics of their hosts. Can Entomol 128:413-433

Leung TLF (2014) Fish as parasites: an insight into evolutionary convergence in adaptations for parasitism. J Zool 294:1-12

Love DC, Shirley TC (1993) Parasitism of the golden king crab, Lithodes aequispinus Benedict, 1895, by a liparid fish. Crustaceana 65: 97-104

Mehbub MF, Lei J, Franco C, Zhang W (2014) Marine sponge derived natural products between 2001 and 2010: trends and opportunities for discovery of bioactives. Mar Drugs 12:4539-4577

Momota K, Munehara H (2017) Reproductive ecology and morphological changes during the early life stages of Pallasina barbata (Steindachner, 1876). Bull Fish Sci Hokkaido Univ 67:7-12

Mills SC, Reynolds JD (2002) Mussel ventilation rates as approximate cue for host selection by bitterling, Rhodeus sericeus. Oecologia 131:473-478

Mills SC, Reynolds JD (2003) The bitterling-mussel interaction as a test case for coevolution. J Fish Biol 63:84-104

Munehara H (1991) Utilization and ecological benefits of a sponge as a spawning bed by the little dragon sculpin Blepsias cirrhosis. Jap J Ichthyol 38:179-184

Munehara H, Goto A, Yabe M (2011) Diversity of Cottoid Fishes -Adaptation and Evolution-. Tokai Univ Press, Kanagawa

Munehara H, Takano K, Koya Y (1989) Internal gametic association and external fertilization in the elkhorn sculpin, Alcichthys alcicornis. Copeia 1989:673-678

Nakabo T, Kai Y (2013) Cottidae. In: Nakabo T (Ed.) Fishes of Japan with pictorial keys to the species third edition. Tokai University Press, Hadano, pp 1160-1188, 2061-2067

Nelson JS, Grande TC, Wilson MVH (2016) Fishes of the World, 5th ed. John Wiley \& Sons, Inc, New Jersey

Nishida T, Inui R, Onikura N (2008) A note on the spawning bed of Pseudoblennius percoides (Scorpaeniformes, Cottidae) in shallow sea areas around coastal Fukutsu, northern Kyusyu Island, Japan. Biogeography 10:45-51

Okamura O, Amaoka K Eds. (1997) Seawater Fishes in Japan. Yamatokeikoku-sha, Tokyo

Paul VJ, Puglisi MP (2004) Chemical mediation of interactions among marine organisms. Nat Prod Rep 21:189-209 
Paul VJ, Puglisi MP, Ritson-Williams R (2006) Marine chemical ecology. Nat Prod Rep 23:153-180

Palumbi SR (1996) What can molecular genetics contribute to marine biogeography? An urchin's tale. J Exp Mar Biol Ecol 203:75-92

Peden AE, Corbett CA (1973) Commensalism between a liparid fish, Careproctus sp., and the lithodid box crab, Lopholithodes foraminatus. Can J Zool 51:555-556

Poltev YN, Mukhametov IN (2009) Concerning the problem of carcinophilia of Careproctus species (Scorpaeniformes: Liparidae) in the North Kurils. Russ J Mar Biol 35:215-223

Reichard M, Liu H, Smith C (2007) The co-evolutionary relationship between bitterling fishes and freshwater mussels: insights from interspecific comparisons. Evol Ecol Res 9:239259

Reichard M, Ondrackova M, Przybylski M, Liu H, Smith C (2006) The costs and benefits in an unusual symbiosis: experimental evidence that bitterling fish (Rhodeus sericeus) are parasites of unionid mussels in Europe. J Evol Biol 19:788-796

Schmidt TR, Gold JR (1993) Complete sequence of the mitochondrial cytochrome $b$ gene in the cherryfin shiner, Lythrurus roseipinnis (Teleostei: Cyprinidae). Copeia 1993:880883

Shinomiya A (1985) Studies on the reproductive physiology and ecology in three marine cottid fish. Dissertation, Hokkaido University

Shinomiya A, Ikemoto M (1987) Spawning habits of the sculpin Pseudoblennius percoides in relation to sea squirt. In: Advance abstracts for the 20th annual meeting, The Ichthyological Society of Japan, p 26

Shiogaki M, Dotsu Y (1974) The spawning of the sea sculpin, Pseudoblennius cottoides. Bull Fac Fish Nagasaki Univ 38:71-76

Smith C, Reichard M, Jurajda P, Przybylski M (2004) The reproductive ecology of the European bitterling (Rhodeus sericeus). J Zool 262:107-124

Smith C, Rippon K, Douglas A, Jurajda P (2001) A proximate cue for oviposition site choice in the bitterling (Rhodeus sericeus). Freshw Biol 46:903-911

Somerton DA, Donaldson W (1998) Parasitism of the golden king crab, Lithodes aequispinus, by two species of snailfish, genus Careproctus. Fish Bull 96:871-884

Spence R, Smith C (2013) Rose bitterling (Rhodeus ocellatus) embryos parasitize freshwater mussels by competing for nutrients and oxygen. Acta Zool 94:113-118

Stoecker D (1980) Chemical defenses of ascidians against predators. Ecology 61:1327-1334

Tamura K, Nei M (1993) Estimation of the number of nucleotide substitutions in the control region of mitochondrial-DNA in humans and chimpanzees. Mol Biol Evol 10:512-526

Uchida K (1932) Fish laying eggs in the body of tunicates. Kagaku 2:56-57

Uchida K (1979) Chigyo Wo Motomete. Iwanamisyoten, Tokyo

Uryu T (2011) Marine Fishes of Izu. Kaiyusha, Tokyo

Yabe M (1985) Comparative osteology and myology of the superfamily Cottoidea (Pisces:

Scorpaeniformes), and its phylogenetic classification. Mem Fac Fish Hokkaido Univ 
$32: 1-130$ 


\section{Figure legends}

Fig. 1 Location of sampling sites. (a) Sado Island located $45 \mathrm{~km}$ north west of Niigata, Japan. We collected sculpins that oviposit on rock surface at Usujiri $\left(41^{\circ} 56^{\prime} 11.85^{\prime \prime} \mathrm{N}, 140^{\circ} 56^{\prime}\right.$ 54.66" E), Hokkaido, Japan. (b) Four sampling sites on the coast of the island. Kitakoura: $38^{\circ}$ $16^{\prime} 26.90^{\prime \prime} \mathrm{N}, 138^{\circ} 30^{\prime} 34.42^{\prime \prime}$ E; Mushizaki: $38^{\circ} 14^{\prime} 58.66^{\prime \prime} \mathrm{N}, 138^{\circ} 30^{\prime} 24.37^{\prime \prime}$ E; Tassya: $38^{\circ}$ 04' 28.64" N, $138^{\circ} 14^{\prime} 40.81^{\prime \prime}$ E and; Kotoura: $37^{\circ} 48^{\prime} 13.43^{\prime \prime}$ N, $138^{\circ} 15^{\prime} 08.26^{\prime \prime}$ E. (c) Kitakoura Port. Monthly collection of tunicates was conducted along the south breakwater of the port (indicated by an ellipse).

Fig. 2 Examples of photographs of eggs deposited in sponges and tunicates. (a) Egg masses deposited by females of Pseudoblennius marmoratus in sponges. (b) Eyed eggs of Vellitor centropomus in a colonial tunicate. (c) Colonial tunicate; at least five egg masses were deposited in this colony. Colony width: c.a. $100 \mathrm{~mm}$. (d) Halocynthia ritteri, the solitary tunicates most frequently used by sculpins. (e) Underwater photograph of $H$. roretzi. (f) Eyed eggs of Ps. cottoides found in H. ritteri. (g) Eyed eggs of Pseudoblennius sp. "Kirin-anahaze" deposited in H. roretzi. (f) Eyed Furcina osimae eggs in Pyura sacciformis. Scale bars indicated in (a), (b), (f), (g) and (h): $10 \mathrm{~mm}$.

Fig. 3 Size frequency distribution of solitary tunicates collected during study periods. (a) Microcosmus hartmeyeri, (b) Herdmania japonica, (c) Halocynthia roretzi, (d) Halocynthia ritteri, (e) Polycarpa cryptocarpa kroboja, (f) Pyura sacciformis and (g) Cnemidocarpa irene. Panels are arranged in decreasing order of the average long diameter (LD) of tunicates. White, grey and black bars indicate tunicates with sculpin egg masses, with Japanese tubesnout egg masses and without any egg masses, respectively. $n_{s c}$ : number of tunicates with sculpin eggs, 
$n_{t u}$ : number of tunicates with eggs of Japanese tubesnout (the details of which will be published in a separate paper) and $n_{n e}$ : number of tunicates with no fish eggs.

Fig. 4 (a) Ovipositor length (OL) increased with standard length (SL) of sculpins and differed among sculpins that utilised four different types of hosts. Circles, triangles and squares denote the species that used solitary tunicates, colonial tunicates and sponges, and rock surfaces as deposition sites, respectively. Regression lines for different types of hosts are from the reduced model of ANCOVA. Relative OL were statistically significantly different between all combinations of the four types (Tukey's HSD, $p<0.05$ ). (b)-(e) Examples of photographs of ovipositors (indicated by the arrows) in the sculpins of the four types. (b) Pseudoblennius cottoides; (c) Vellitor centropomus; (d) Ps. marmoratus; and (e) Alcichthys alcicornis. Scale bars: $10 \mathrm{~mm}$.

Fig. 5 Body size and ovipositor length of parasitic sculpins were closely related to the size of solitary tunicates selected by each sculpin species as spawning hosts. (a) Female standard length (SL) and (b) ovipositor length (OL) of six species of sculpins that used solitary tunicates as hosts. (c) Long diameter (LD) and (d) egg mass position of tunicates utilised as hosts. Means ( $\pm \mathrm{SD}$ ) with different letters are significantly different (Tukey's HSD, $p<0.05$ ). Sample sizes are indicated as numerals in bars. $N D$, no data. Bars are arranged in decreasing order of the average SL of sculpins from left to right. 


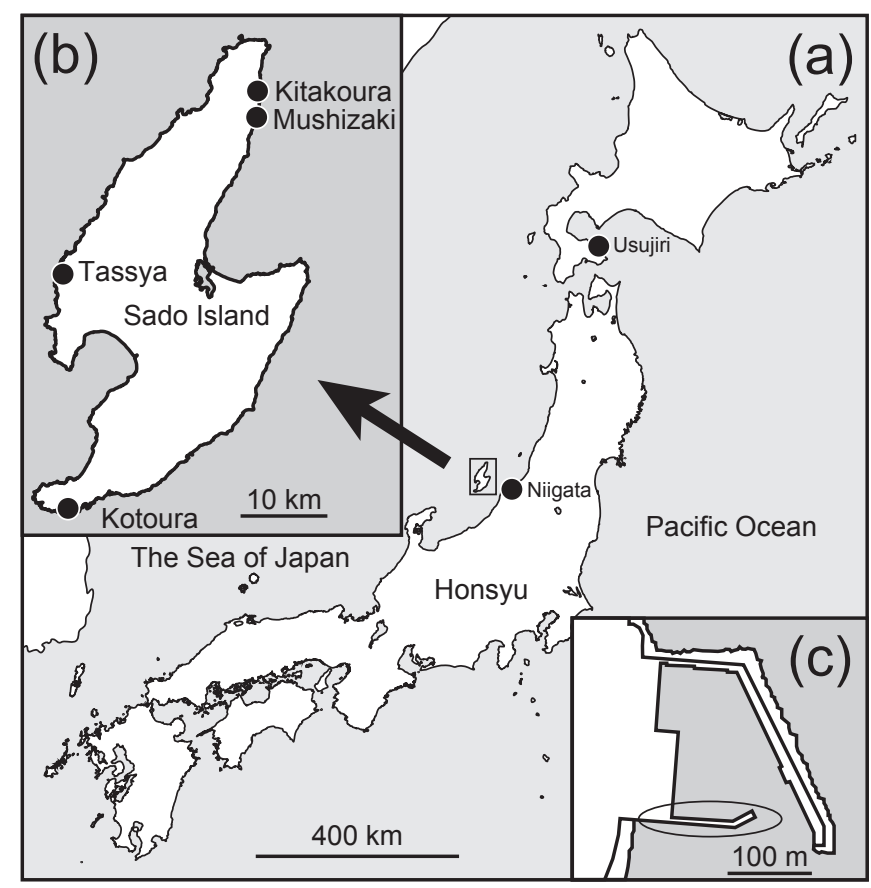

Figure 1 

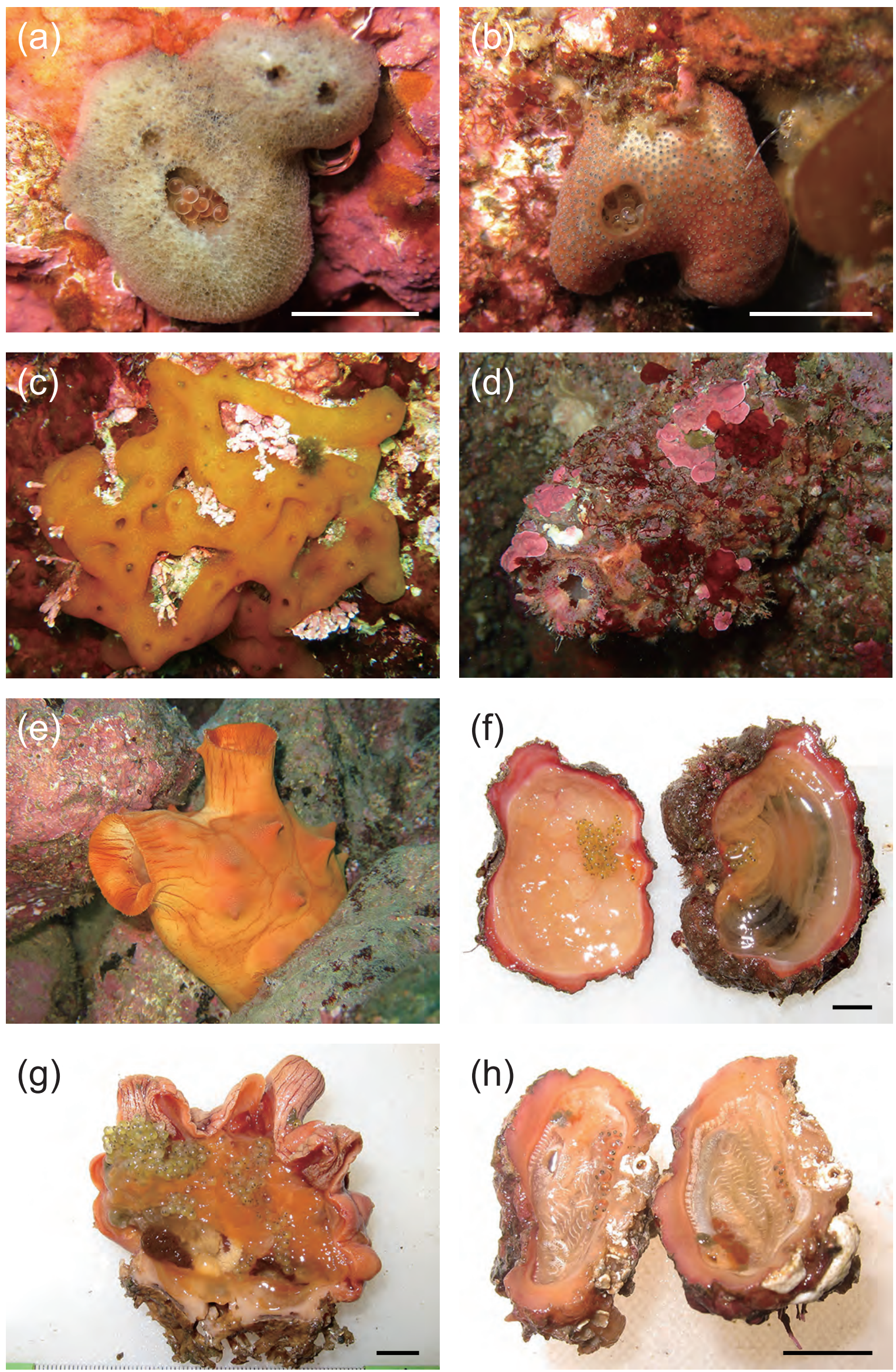

Figure 2 


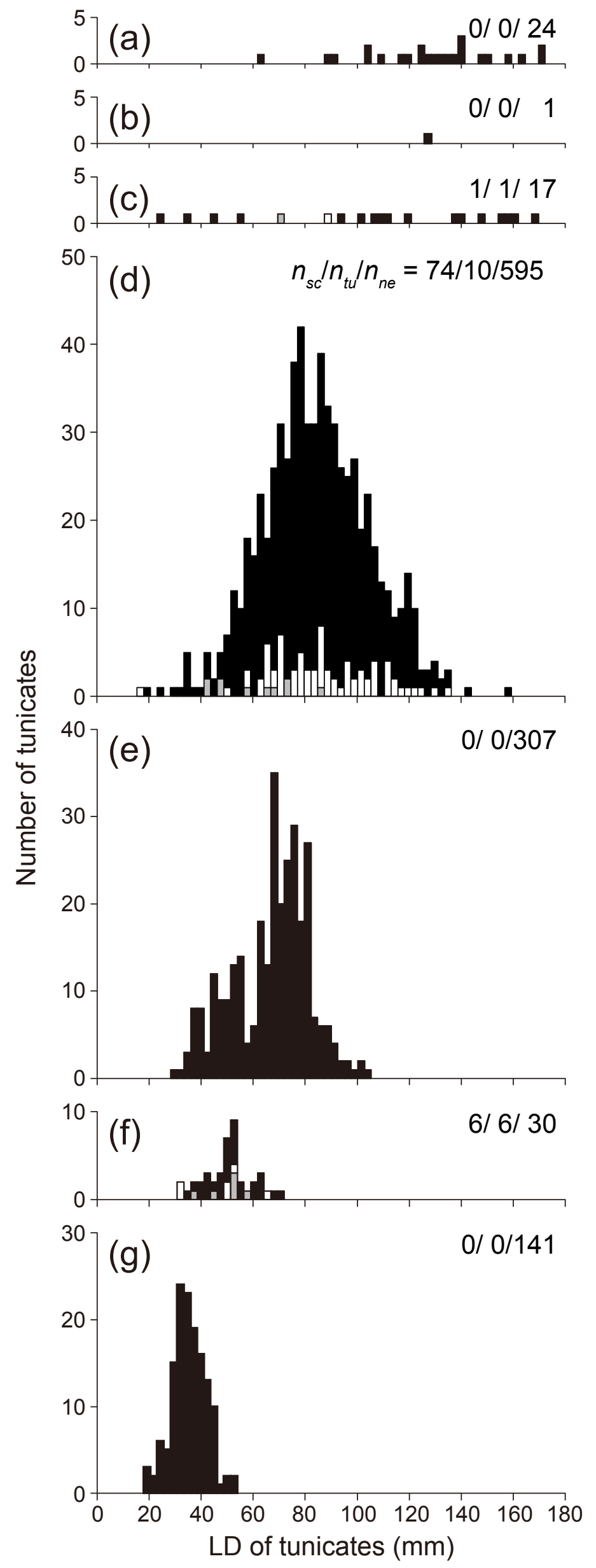

Figure 3 

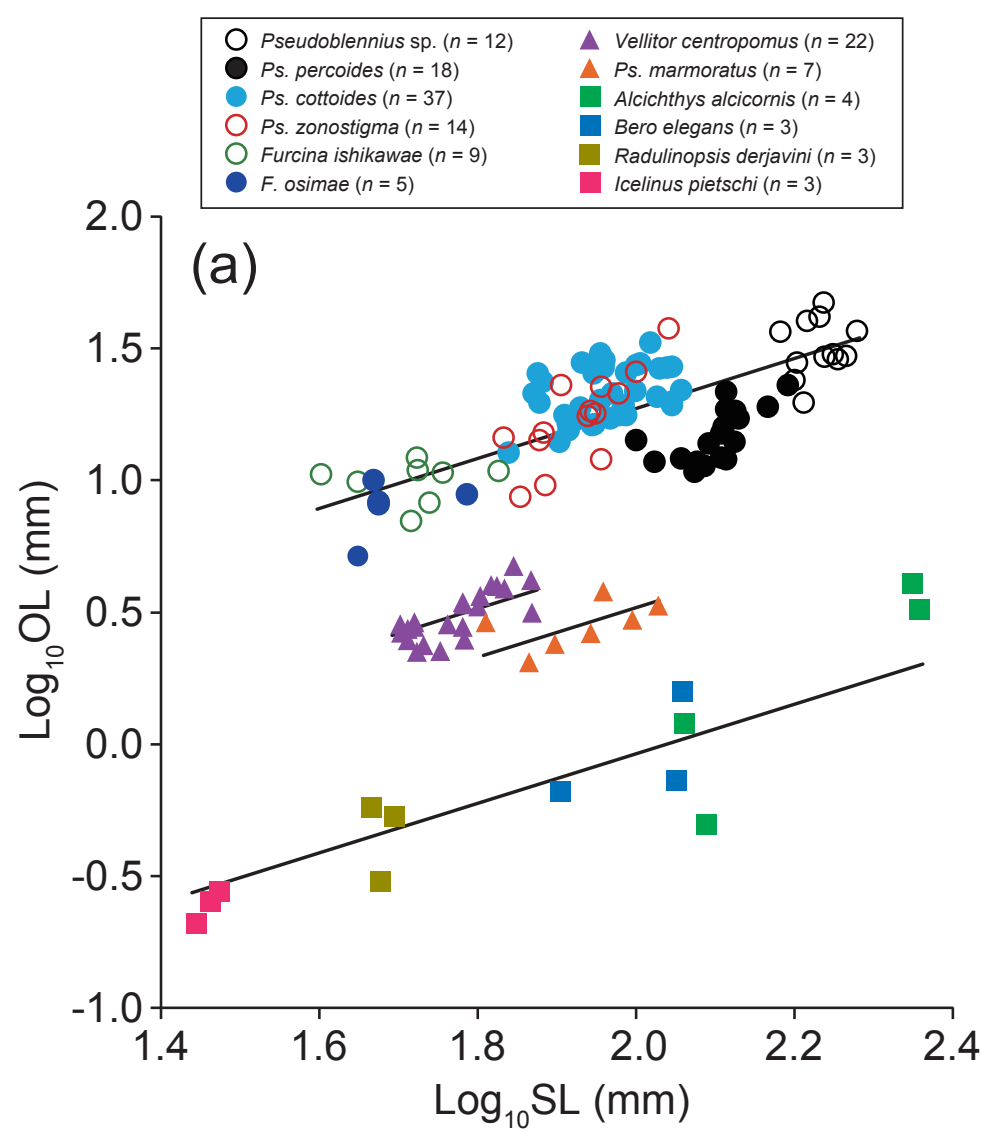

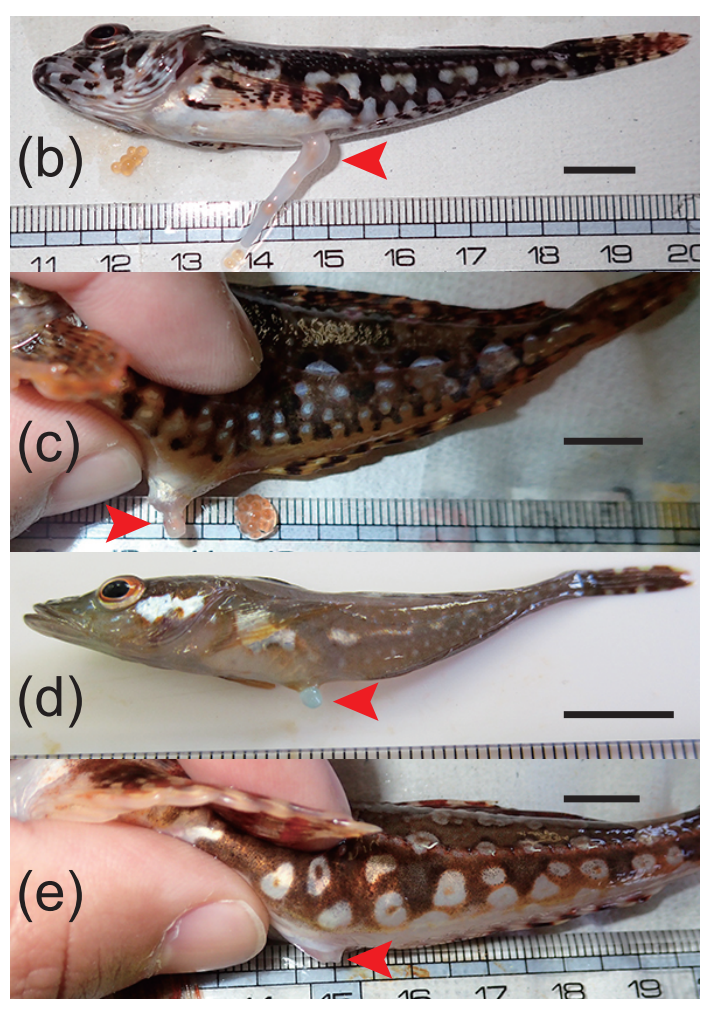

Figure 4 

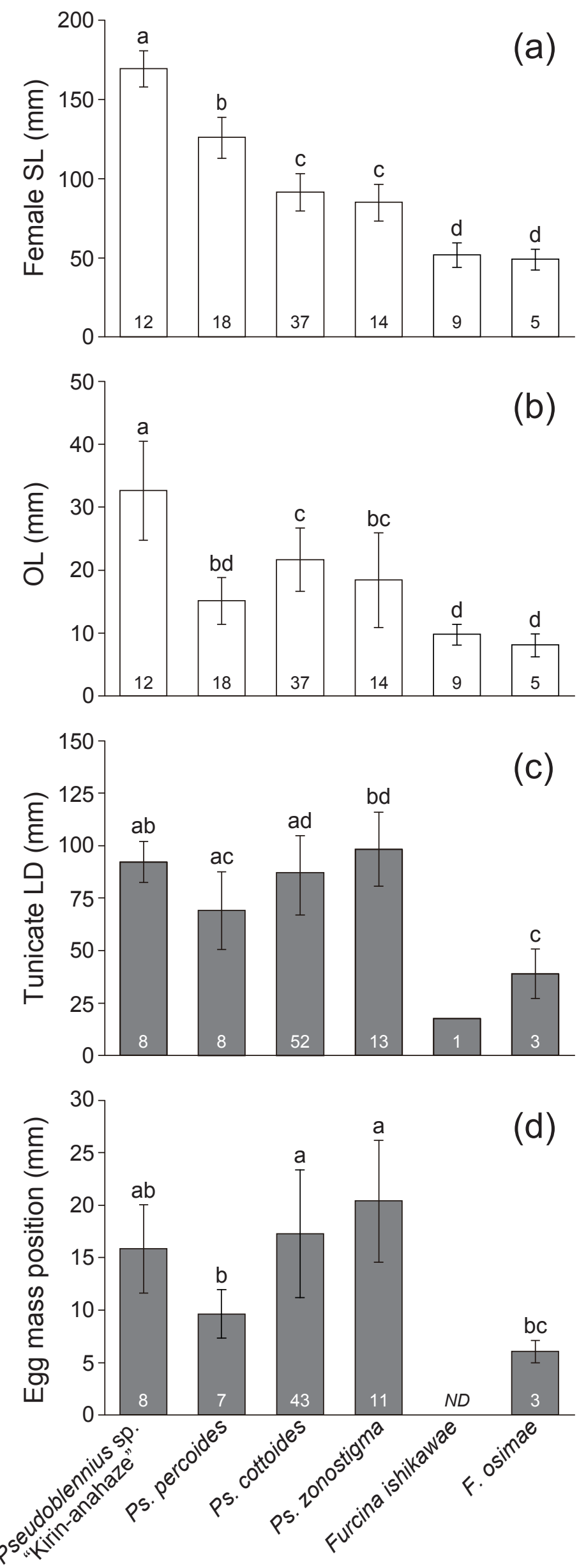

Figure 5 
Table 1 Host (solitary tunicates) use by sculpins and Japanese tubesnout. The number of tunicates where single, double and triple cluches of fish were found is shown in parenthesis.

\begin{tabular}{|c|c|c|c|c|c|c|c|c|c|}
\hline \multirow[b]{2}{*}{ Host tunicate species } & \multirow[b]{2}{*}{$\begin{array}{l}\text { Total number } \\
\text { of tunicates }\end{array}$} & \multirow[b]{2}{*}{$\begin{array}{l}\text { Total number of tunicates } \\
\text { with sculpin egg masses }\end{array}$} & \multicolumn{6}{|c|}{ Number of tunicates used by sculpins } & \multirow[b]{2}{*}{$\begin{array}{l}\text { Number of tunicates used } \\
\text { by Aulichthys japonicus }\end{array}$} \\
\hline & & & $\begin{array}{l}\text { Pseudoblennius } \\
\text { cottoides }\end{array}$ & Ps. zonostigma & $\begin{array}{l}\text { Pseudoblennius sp. Ps. percoides } \\
\text { "Kirin-anahaze" }\end{array}$ & $\begin{array}{l}\text { Furcina } \\
\text { osimae }\end{array}$ & F. ishikawae & Unidentified & \\
\hline Halocynthia ritteri & 678 & $75(69,5,1)$ & $46(42,3,1)$ & $11(9,2,0)$ & 8 & 6 & 0 & 1 & $10(9,1,0)$ \\
\hline Polycarpa cryptocarpa kroboja & 307 & 0 & 0 & 0 & 0 & 0 & 0 & 0 & 0 \\
\hline Cnemidocarpa irene & 141 & 0 & 0 & 0 & 0 & 0 & 0 & 0 & 0 \\
\hline Pyura sacciformis & 42 & 6 & 1 & 0 & 0 & 2 & 3 & 0 & $6(5,0,1)$ \\
\hline Microcosmus hartmeyeri & 24 & 0 & 0 & 0 & 0 & 0 & 0 & 0 & 0 \\
\hline Halocynthia roretzi & 19 & 1 & 0 & 0 & 1 & 0 & 0 & 0 & 1 \\
\hline Herdmania japonica & 1 & 0 & 0 & 0 & 0 & 0 & 0 & 0 & 0 \\
\hline Total & 1212 & $82(76,5,1)$ & $47(43,3,1)$ & $11(9,2,0)$ & 9 & 8 & 3 & 1 & $17(15,1,1)$ \\
\hline
\end{tabular}




\section{Electronic Supplementary Material}

\section{Marine Biology}

\section{Host selection and ovipositor length in eight sympatric species of sculpins that deposit their}

eggs into tunicates or sponges

Satoshi Awata ${ }^{1,2} \cdot$ Haruka Sasaki $^{2} \cdot$ Tomohito Goto $^{2} \cdot$ Yasunori Koya $^{3} \cdot$ Hirohiko Takeshima $^{4,5} \cdot$ Aya Yamazaki $^{6} \cdot$ Hiroyuki Munehara $^{6}$

${ }^{1}$ Laboratory of Animal Sociology, Graduate School of Science, Osaka City University, Osaka, Japan, ${ }^{2}$ Sado Marine Biological Station, Faculty of Science, Niigata University, Sado, Japan, ${ }^{3}$ Department of Biology, Faculty of Education, Gifu University, Gifu, Japan, ${ }^{4}$ Department of Marine Biology, School of Marine Science and Technology, Tokai University, Shizuoka, Japan, ${ }^{5}$ Research Institute for Humanity and Nature, Kyoto, Japan, ${ }^{6}$ Usujiri Fisheries Station, Field Science Center for Northern Biosphere, Hokkaido University, Hakodate, Japan

Correspondence

Satoshi Awata

Laboratory of Animal Sociology, Graduate School of Science, Osaka City University, 3-3-138 Sugimoto, Sumiyoshi, Osaka 5588585 , Japan.

Tel.: +81666052607

e-mail: sa-awata@sci.osaka-cu.ac.jp 
Table S1 Individual identity, scientific name, collection site, collection date and GenBank accession number of sculpins used for parental species identification in this study.

\begin{tabular}{|c|c|c|c|c|}
\hline Ind. ID & Scientific name & Collection site & Collection date & Accession No. \\
\hline Pseudoblennius percoides -1 & Pseudoblennius percoides & Tassya, Sado, Japan & November-11 & LC424805 \\
\hline Pseudoblennius percoides -9 & Pseudoblennius percoides & Sado, Japan & October-13 & LC424806 \\
\hline Pseudoblennius percoides -10 & Pseudoblennius percoides & Sado, Japan & October-13 & same sequence as LC424806 \\
\hline Pseudoblennius percoides -11 & Pseudoblennius percoides & Sado, Japan & October-13 & same sequence as LC424806 \\
\hline Pseudoblennius percoides -12 & Pseudoblennius percoides & Sado, Japan & October-13 & same sequence as LC424806 \\
\hline Pseudoblennius percoides -13 & Pseudoblennius percoides & Sado, Japan & October-13 & same sequence as LC424806 \\
\hline Pseudoblennius percoides -14 & Pseudoblennius percoides & Sado, Japan & October-13 & same sequence as LC424806 \\
\hline Pseudoblennius percoides -15 & Pseudoblennius percoides & Sado, Japan & October-13 & same sequence as LC424806 \\
\hline Pseudoblennius percoides -16 & Pseudoblennius percoides & Sado, Japan & October-13 & same sequence as LC424806 \\
\hline Pseudoblennius percoides -17 & Pseudoblennius percoides & Sado, Japan & October-13 & same sequence as LC424806 \\
\hline Pseudoblennius percoides -18 & Pseudoblennius percoides & Sado, Japan & October-13 & same sequence as LC424806 \\
\hline Pseudoblennius percoides -19 & Pseudoblennius percoides & Sado, Japan & October-13 & LC424807 \\
\hline Pseudoblennius percoides -20 & Pseudoblennius percoides & Sado, Japan & October-13 & same sequence as LC424806 \\
\hline Pseudoblennius percoides -21 & Pseudoblennius percoides & Sado, Japan & October-13 & same sequence as LC424806 \\
\hline Pseudoblennius sp.-1 & Pseudoblennius sp. ("Kirin-anahaze") & Tassya, Sado, Japan & July-13 & LC424808 \\
\hline Pseudoblennius sp.-3 & Pseudoblennius sp. ("Kirin-anahaze") & Sado, Japan & October-13 & same sequence as LC424808 \\
\hline Pseudoblennius sp.-4 & Pseudoblennius sp. ("Kirin-anahaze") & Sado, Japan & October-13 & same sequence as LC424808 \\
\hline Pseudoblennius sp.-6 & Pseudoblennius sp. ("Kirin-anahaze") & Sado, Japan & October-13 & same sequence as LC424808 \\
\hline Pseudoblennius sp.-7 & Pseudoblennius sp. ("Kirin-anahaze") & Sado, Japan & October-13 & same sequence as LC424808 \\
\hline Pseudoblennius sp.-8 & Pseudoblennius sp. ("Kirin-anahaze") & Sado, Japan & October-13 & same sequence as LC424808 \\
\hline Pseudoblennius sp.-9 & Pseudoblennius sp. ("Kirin-anahaze") & Sado, Japan & October-13 & same sequence as LC424808 \\
\hline Pseudoblennius sp.-15 & Pseudoblennius sp. ("Kirin-anahaze") & Sado, Japan & October-13 & same sequence as LC424808 \\
\hline Pseudoblennius sp.-18 & Pseudoblennius sp. ("Kirin-anahaze") & Sado, Japan & October-13 & same sequence as LC424808 \\
\hline Pseudoblennius sp.-19 & Pseudoblennius sp. ("Kirin-anahaze") & Sado, Japan & October-13 & same sequence as LC424808 \\
\hline Pseudoblennius sp.-23 & Pseudoblennius sp. ("Kirin-anahaze") & Sado, Japan & October-13 & same sequence as LC424808 \\
\hline Pseudoblennius sp.-24 & Pseudoblennius sp. ("Kirin-anahaze") & Sado, Japan & October-13 & same sequence as LC424808 \\
\hline Pseudoblennius cottoides -18 & Pseudoblennius cottoides & Tassya, Sado, Japan & December-11 & LC424812 \\
\hline Pseudoblennius cottoides -24 & Pseudoblennius cottoides & Kitakoura, Sado, Japan & December-12 & LC424810 \\
\hline Pseudoblennius cottoides -37 & Pseudoblennius cottoides & Sado, Japan & October-13 & same sequence as LC424812 \\
\hline Pseudoblennius cottoides -46 & Pseudoblennius cottoides & Mushizaki, Sado, Japan & December-13 & same sequence as LC424812 \\
\hline Pseudoblennius cottoides -47 & Pseudoblennius cottoides & Mushizaki, Sado, Japan & December-13 & same sequence as LC424812 \\
\hline Pseudoblennius cottoides -48 & Pseudoblennius cottoides & Mushizaki, Sado, Japan & December-13 & LC424809 \\
\hline Pseudoblennius cottoides -50 & Pseudoblennius cottoides & Mushizaki, Sado, Japan & December-13 & LC424811 \\
\hline Pseudoblennius cottoides -51 & Pseudoblennius cottoides & Tassya, Sado, Japan & November-14 & same sequence as LC424812 \\
\hline Pseudoblennius cottoides -52 & Pseudoblennius cottoides & Mushizaki, Sado, Japan & January-15 & same sequence as LC424811 \\
\hline Pseudoblennius cottoides -53 & Pseudoblennius cottoides & Mushizaki, Sado, Japan & January-15 & same sequence as LC424812 \\
\hline Pseudoblennius marmoratus -2 & Pseudoblennius marmoratus & Tassya, Sado, Japan & November-11 & LC424813 \\
\hline Pseudoblennius marmoratus -7 & Pseudoblennius marmoratus & Tassya, Sado, Japan & November-11 & same sequence as LC424813 \\
\hline Pseudoblennius marmoratus -9 & Pseudoblennius marmoratus & Kotoura, Sado, Japan & December-11 & same sequence as LC424813 \\
\hline Pseudoblennius marmoratus -10 & Pseudoblennius marmoratus & Tassya, Sado, Japan & December-11 & same sequence as LC424813 \\
\hline Pseudoblennius marmoratus -11 & Pseudoblennius marmoratus & Tassya, Sado, Japan & December-11 & LC424814 \\
\hline Pseudoblennius marmoratus -12 & Pseudoblennius marmoratus & Tassya, Sado, Japan & July-13 & same sequence as LC424813 \\
\hline Pseudoblennius marmoratus -13 & Pseudoblennius marmoratus & Tassya, Sado, Japan & July-13 & same sequence as LC424813 \\
\hline Pseudoblennius marmoratus -15 & Pseudoblennius marmoratus & Tassya, Sado, Japan & August-13 & same sequence as LC424813 \\
\hline Pseudoblennius marmoratus -16 & Pseudoblennius marmoratus & Tassya, Sado, Japan & August-13 & same sequence as LC424813 \\
\hline Pseudoblennius marmoratus -17 & Pseudoblennius marmoratus & Tassya, Sado, Japan & August-13 & same sequence as LC424813 \\
\hline Pseudoblennius marmoratus -18 & Pseudoblennius marmoratus & Tassya, Sado, Japan & August-13 & same sequence as LC424813 \\
\hline Pseudoblennius marmoratus -19 & Pseudoblennius marmoratus & Sado, Japan & October-13 & same sequence as LC424813 \\
\hline Pseudoblennius marmoratus -20 & Pseudoblennius marmoratus & Sado, Japan & October-13 & same sequence as LC424813 \\
\hline Pseudoblennius marmoratus -21 & Pseudoblennius marmoratus & Sado, Japan & October-13 & same sequence as LC424813 \\
\hline Pseudoblennius marmoratus -22 & Pseudoblennius marmoratus & Sado, Japan & October-13 & same sequence as LC424813 \\
\hline Pseudoblennius marmoratus -24 & Pseudoblennius marmoratus & Sado, Japan & October-13 & same sequence as LC424813 \\
\hline Vellitor minutus -1 & Vellitor minutus & Tassya, Sado, Japan & December-11 & LC424815 \\
\hline Vellitor minutus -2 & Vellitor minutus & Tassya, Sado, Japan & October-13 & same sequence as LC424815 \\
\hline Vellitor minutus -3 & Vellitor minutus & Tassya, Sado, Japan & October-13 & same sequence as LC424815 \\
\hline Vellitor minutus -4 & Vellitor minutus & Tassya, Sado, Japan & October-13 & same sequence as LC424815 \\
\hline Vellitor minutus -5 & Vellitor minutus & Tassya, Sado, Japan & November-15 & same sequence as LC424815 \\
\hline Vellitor minutus -6 & Vellitor minutus & Tassya, Sado, Japan & November-15 & same sequence as LC424815 \\
\hline Vellitor minutus -7 & Vellitor minutus & Tassya, Sado, Japan & November-15 & same sequence as LC424815 \\
\hline Vellitor minutus -8 & Vellitor minutus & Tassya, Sado, Japan & November-15 & same sequence as LC424815 \\
\hline Vellitor centropomus -1 & Vellitor centropomus & Kotoura, Sado, Japan & November-12 & $\mathrm{LC} 424820$ \\
\hline Vellitor centropomus -2 & Vellitor centropomus & Kotoura, Sado, Japan & November-12 & same sequence as LC424820 \\
\hline Vellitor centropomus -3 & Vellitor centropomus & Kotoura, Sado, Japan & November-12 & same sequence as LC424820 \\
\hline Vellitor centropomus -4 & Vellitor centropomus & Kotoura, Sado, Japan & November-12 & same sequence as LC424820 \\
\hline Vellitor centropomus -5 & Vellitor centropomus & Kotoura, Sado, Japan & November-12 & LC424817 \\
\hline Vellitor centropomus -6 & Vellitor centropomus & Kotoura, Sado, Japan & November-12 & same sequence as LC424820 \\
\hline Vellitor centropomus -7 & Vellitor centropomus & Kotoura, Sado, Japan & November-12 & LC424816 \\
\hline Vellitor centropomus -9 & Vellitor centropomus & Kotoura, Sado, Japan & November-12 & same sequence as LC424820 \\
\hline Vellitor centropomus -10 & Vellitor centropomus & Kotoura, Sado, Japan & November-12 & same sequence as LC424820 \\
\hline Vellitor centropomus -11 & Vellitor centropomus & Kotoura, Sado, Japan & November-12 & same sequence as LC424820 \\
\hline Vellitor centropomus -12 & Vellitor centropomus & Kitakoura, Sado, Japan & November-12 & LC424818 \\
\hline Vellitor centropomus $-12-2$ & Vellitor centropomus & Kotoura, Sado, Japan & April-12 & same sequence as LC424820 \\
\hline Vellitor centropomus -13 & Vellitor centropomus & Kitakoura, Sado, Japan & November-12 & same sequence as LC424820 \\
\hline Vellitor centropomus -14 & Vellitor centropomus & Kitakoura, Sado, Japan & November-12 & same sequence as LC424820 \\
\hline Vellitor centropomus -15 & Vellitor centropomus & Kitakoura, Sado, Japan & November-12 & same sequence as LC424820 \\
\hline Vellitor centropomus -16 & Vellitor centropomus & Kitakoura, Sado, Japan & December-12 & same sequence as LC424820 \\
\hline
\end{tabular}


Vellitor centropomus -17

Vellitor centropomus -18

Vellitor centropomus -19

Vellitor centropomus -20

Vellitor centropomus -21

Vellitor centropomus -22

Vellitor centropomus -23

Vellitor centropomus -24

Pseudoblennius zonostigma -3

Pseudoblennius zonostigma-4

Pseudoblennius zonostigma-7

Pseudoblennius zonostigma-8

Pseudoblennius zonostigma -9

Pseudoblennius zonostigma -12

Pseudoblennius zonostigma-13

Pseudoblennius zonostigma -15

Pseudoblennius zonostigma-16

Pseudoblennius zonostigma -17

Pseudoblennius zonostigma-18

Furcina osimae-16

Furcina osimae -19

Furcina osimae -20

Furcina osimae -27

Furcina osimae -37

Furcina osimae -38

Furcina osimae -39

Furcina osimae -43

Furcina osimae -44

Furcina osimae -45

Furcina osimae -47

Furcina osimae -48

Furcina osimae -49

Furcina osimae -50

Furcina osimae -51

Furcina osimae -52

Furcina osimae -57

Furcina osimae -58

Furcina osimae -62

Furcina ishikawae-1

Furcina ishikawae-2

Furcina ishikawae-3

Furcina ishikawae-5

Furcina ishikawae-6

Furcina ishikawae-7

Furcina ishikawae-8

Furcina ishikawae-9

Furcina ishikawae -10

Furcina ishikawae-11

Furcina ishikawae-12

Furcina ishikawae-13

Furcina ishikawae-14

Furcina ishikawae-15

Furcina ishikawae-16

Furcina ishikawae-33

Jordania zonope -4

Jordania zonope -6
Vellitor centropomus

Vellitor centropomus

Vellitor centropomus

Vellitor centropomus

Vellitor centropomus

Vellitor centropomus

Vellitor centropomus

Vellitor centropomus

Pseudoblennius zonostigma

Pseudoblennius zonostigma

Pseudoblennius zonostigma

Pseudoblennius zonostigma

Pseudoblennius zonostigma

Pseudoblennius zonostigma

Pseudoblennius zonostigma

Pseudoblennius zonostigma

Pseudoblennius zonostigma

Pseudoblennius zonostigma

Pseudoblennius zonostigma

Furcina osimae

Furcina osimae

Furcina osimae

Furcina osimae

Furcina osimae

Furcina osimae

Furcina osimae

Furcina osimae

Furcina osimae

Furcina osimae

Furcina osimae

Furcina osimae

Furcina osimae

Furcina osimae

Furcina osimae

Furcina osimae

Furcina osimae

Furcina osimae

Furcina osimae

Furcina ishikawae

Furcina ishikawae

Furcina ishikawae

Furcina ishikawae

Furcina ishikawae

Furcina ishikawae

Furcina ishikawae

Furcina ishikawae

Furcina ishikawae

Furcina ishikawae

Furcina ishikawae

Furcina ishikawae

Furcina ishikawae

Furcina ishikawae

Furcina ishikawae

Furcina ishikawae

Jordania zonope

Jordania zonope
Kitakoura, Sado, Japan March-13

Kitakoura, Sado, Japan March-13

Tassya, Sado, Japan October-13

Tassya, Sado, Japan October-13

Tassya, Sado, Japan October-13

Sado, Japan November-13

Sado, Japan November-13

Sado, Japan November-13

Kitakoura, Sado, Japan December-12

Kitakoura, Sado, Japan December-12

Tassya, Sado, Japan November-14

Kotoura, Sado, Japan April-15

Kotoura, Sado, Japan April-15

Mushizaki, Sado, Japan February-16

Mushizaki, Sado, Japan September-16

Kotoura, Sado, Japan October-16

Tassya, Sado, Japan December-16

Mushizaki, Sado, Japan December-16

Mushizaki, Sado, Japan December-16

Tassya, Sado, Ja

Tassya, Sado, Japan

Tassya, Sado, Japan

Tassya, Sado, Japan

Sado, Japan

Sado, Japan

Sado, Japan

Sado, Japan

Sado, Japan

Sado, Japan

Mushizaki, Sado, Japan

Mushizaki, Sado, Japan

Tassya, Sado, Japan

Tassya, Sado, Japan

Tassya, Sado, Japan

Tassya, Sado, Japan

Tassya, Sado, Japan

Tassya, Sado, Japan

Kotoura, Sado, Japan

Kotoura, Sado, Japan

Kitakoura, Sado, Japan

Kitakoura, Sado, Japan

Kitakoura, Sado, Japan

Kitakoura, Sado, Japan

Kitakoura, Sado, Japan

Kitakoura, Sado, Japan

Kitakoura, Sado, Japan

Kitakoura, Sado, Japan

Kitakoura, Sado, Japan

Kitakoura, Sado, Japan

Kitakoura, Sado, Japan

Kitakoura, Sado, Japan

Kitakoura, Sado, Japan

Kitakoura, Sado, Japan

Kotoura, Sado, Japan

Ucluelet, BC, Canada

Ucluelet, BC, Canada

February-17 same sequence as LC424816 same sequence as LC424820 same sequence as LC424820 same sequence as LC424820 same sequence as LC424820 same sequence as LC424820 LC424819

same sequence as LC424820 LC424821

LC424822

same sequence as LC424822 same sequence as LC424822 same sequence as LC424821 same sequence as LC424822 same sequence as LC424821 same sequence as LC424822 same sequence as LC424822 same sequence as LC424822 same sequence as LC424822 LC424823

LC424824

same sequence as LC424823 same sequence as LC424823 same sequence as LC424823 same sequence as LC424823 same sequence as LC424823 same sequence as LC424823 same sequence as LC424823 same sequence as LC424823 same sequence as LC424824 same sequence as LC424824 same sequence as LC424823 same sequence as LC424823 same sequence as LC424824 same sequence as LC424823 same sequence as LC424823 same sequence as LC424823 same sequence as LC424823 LC424825

same sequence as LC424825 same sequence as LC424825

LC424826

LC424827

same sequence as LC424825 same sequence as LC424825 LC424828

LC424829

LC424830

same sequence as LC424826 same sequence as LC424826 LC424831

LC424832

same sequence as LC424826 same sequence as LC424826

February-17 LC424833

December-15 
Table S2 Results of genetic identification of parental species of egg masses deposited in colonial tunicates and sponges. Sampling date, locality, depth, water temperature (WT), number of eggs in hosts, number of hatched larvae, the average egg diameter, egg (yolk) coloration and number of young analyzed for genetic species identification are shown. $N D$, no data.

mber Number of Dverage eg

\begin{tabular}{|c|c|c|c|c|c|c|c|c|c|c|c|c|c|c|}
\hline No & Egg mass ID & Fish species & Host ID & Host animal & Host species & Date & Locality & Depth (m) & WT $\left({ }^{\circ} \mathrm{C}\right)$ & $\begin{array}{l}\begin{array}{l}\text { Number } \\
\text { of eggs }\end{array} \\
\text { on }\end{array}$ & $\begin{array}{l}\text { Number of } \\
\text { hatched larva }\end{array}$ & $\begin{array}{l}\text { Diameter } \\
(\mathrm{mm})\end{array}$ & Egg (yolk) coloration & $\begin{array}{l}\text { Number of } \\
\text { analyzed young }\end{array}$ \\
\hline 1 & SPE-001 & Vellitor centropomus & $\begin{array}{ll}\text { SP-0001 } \\
\end{array}$ & $\begin{array}{l}\text { Colonial tunicate } \\
\end{array}$ & Didemnidae sp. & 02-Apr-12 & Kotoura & $7.0-9.0$ & 9.2 & & 15 & $1.4(N=10)$ & Orange & \\
\hline 2 & SPE-002 & Vellitor centropoтиs & SP-0001 & Colonial tunicate & Didemnidae sp. & 02-Apr-12 & Kotoura & $7.0-9.0$ & 9.2 & & 124 & $1.4(10)$ & Orange, yellow, clear & 3 \\
\hline 3 & SPE-003 & Vellitor centropomus & SP-0001 & Colonial tunicate & Didemnidae sp. & 02-Apr-12 & Kotoura & $7.0-9.0$ & 9.2 & 138 & 57 & $1.4(10)$ & Orange & 3 \\
\hline 4 & SPE-004 & Vellitor centropomus & SP-0002 & Colonial tunicate & Didemnidae sp. & 02-Apr-12 & Kotoura & $7.0-9.0$ & 9.2 & & 11 & $1.3(10)$ & Yellow & 2 \\
\hline 5 & SPE-006 & Vellitor centropomus & SP-0007 & Colonial tunicate & Didemnidae sp. & 15-Apr-12 & Kotoura & $8.0-12.0$ & 9.4 & 29 & 16 & $1.4(10)$ & Yellow & 3 \\
\hline 6 & SPE-008 & Vellitor centropoтиs & SP-0014 & Colonial tunicate & Didemnidae sp. & 15-Apr-12 & Kotoura & $8.0-12.0$ & 9.4 & 121 & 2 & $1.4(10)$ & Yellow & 2 \\
\hline 7 & SPE-011 & Vellitor centropomus & SP-0014 & Colonial tunicate & Didemnidae sp. & 15-Apr-12 & Kotoura & $8.0-12.0$ & 9.4 & 95 & 1 & $1.4(10)$ & Orange & 1 \\
\hline 8 & SPE-014 & Vellitor centropomus & SP-0025 & Colonial tunicate & Didemnidae sp. & 02-May-12 & Kotoura & $6.0-9.0$ & 13.6 & 54 & 1 & $\mathrm{ND}$ & Yellow & 1 \\
\hline 9 & SPE-015 & Vellitor centropomus & SP-0027 & Sponge & Demospongiae sp. & 05-May-12 & Kotoura & $4.0-7.0$ & 9.7 & 6 & 1 & $1.3(6)$ & Yellow & 2 \\
\hline 10 & SPE-016 & Vellitor centropomus & SP-0031 & Colonial tunicate & Didemnidae sp. & 05-May-12 & Kotoura & $4.0-7.0$ & 9.7 & 25 & 0 & $1.4(10)$ & Yellow & 1 \\
\hline 11 & SPE-017 & Vellitor centropomus & SP-0031 & Colonial tunicate & Didemnidae sp. & 05-May-12 & Kotoura & $4.0-7.0$ & 9.7 & 33 & 31 & $1.3(10)$ & Yellow & 2 \\
\hline 12 & SPE-018 & Vellitor centropomus & SP-0032 & Sponge & Demospongiae sp. & 05-May-12 & Kotoura & $4.0-7.0$ & 9.7 & 8 & 8 & $1.3(5)$ & Yellow & 2 \\
\hline 13 & SPE-020 & Vellitor centropomus & SP-0034 & Colonial tunicate & Didemnidae sp. & 20-Mar-13 & Kotoura & $6.0-8.0$ & 10.4 & 85 & 85 & $1.3(10)$ & Yellow & 3 \\
\hline 14 & SPE-021 & Vellitor centropomus & SP-0035 & Colonial tunicate & Didemnidae sp. & 20-Mar-13 & Kotoura & $6.0-8.0$ & 10.4 & 82 & 82 & $1.3(8)$ & Yellow & 3 \\
\hline 15 & SPE-022 & Vellitor centropomus & SP-0036 & Colonial tunicate & Didemnidae sp. & 20-Mar-13 & Kotoura & $6.0-8.0$ & 10.4 & 29 & 21 & $1.3(9)$ & Yellow & 3 \\
\hline 16 & SPE-023A & Vellitor centropomus & SP-0037 & Colonial tunicate & Didemnidae sp. & 20-Mar-13 & Kotoura & $6.0-8.0$ & 10.4 & 40 & 1 & $1.3(10)$ & Yellow & 3 \\
\hline 17 & SPE-023B & Vellitor centropomus & SP-0037 & Colonial tunicate & Didemnidae sp. & 20-Mar-13 & Kotoura & $6.0-8.0$ & 10.4 & 63 & 47 & $1.3(10)$ & Yellow & 3 \\
\hline 18 & SPE-024 & Vellitor centropomus & SP-0038 & Colonial tunicate & Didemnidae sp. & 20-Mar-13 & Kotoura & $6.0-8.0$ & 10.4 & 79 & 69 & $1.2(10)$ & Yellow & 3 \\
\hline 19 & SPE-026 & Vellitor centropomus & SP-0040 & Colonial tunicate & Didemnidae sp. & 26-Apr-13 & Kotoura & $8.0-11.0$ & 10.8 & 68 & 29 & $1.4(10)$ & Yellow & 2 \\
\hline 20 & SPE-027A & Vellitor centropomus & SP-0041 & Colonial tunicate & Didemnidae sp. & 26-Apr-13 & Kotoura & $8.0-11.0$ & 10.8 & 66 & 66 & $1.4(10)$ & Yellow & 2 \\
\hline 21 & SPE-027B & Vellitor centropomus & SP-0041 & Colonial tunicate & Didemnidae sp. & 26-Apr-13 & Kotoura & $8.0-11.0$ & 10.8 & 46 & 46 & $1.3(10)$ & Yellow & 2 \\
\hline 22 & SPE-029 & Vellitor centropomus & SP-0043 & Colonial tunicate & Didemnidae sp. & 26-Apr-13 & Kotoura & $8.0-11.0$ & 10.8 & 19 & 19 & $1.3(10)$ & Yellow & 2 \\
\hline 23 & SPE-030 & Vellitor centropomus & SP-0044 & Colonial tunicate & Didemnidae sp. & 26-Apr-13 & Kotoura & $8.0-11.0$ & 10.8 & 33 & 33 & $1.3(10)$ & Yellow & 3 \\
\hline 24 & SPE-031 & Vellitor centropoтus & SP-0045 & Colonial tunicate & Didemnidae sp. & 26-Apr-13 & Kotoura & $8.0-11.0$ & 10.8 & 49 & 42 & $1.4(10)$ & Yellow & 2 \\
\hline 25 & SPE-032A & Vellitor centropomus & SP-0046 & Colonial tunicate & Didemnidae sp. & 26-Apr-13 & Kotoura & $8.0-11.0$ & 10.8 & 31 & 23 & $1.3(10)$ & Yellow & 3 \\
\hline 26 & SPE-032B & Vellitor centropomus & SP-0046 & Colonial tunicate & Didemnidae sp. & 26-Apr-13 & Kotoura & $8.0-11.0$ & 10.8 & 53 & 12 & $1.3(10)$ & Yellow & 2 \\
\hline 27 & SPE-034 & Vellitor centropomus & SP-0048 & Sponge & Demospongiae sp. & 06-Mar-14 & Kitakoura & 2.0 & 8.8 & 21 & 5 & ND & Yellow & 2 \\
\hline 28 & SPE-035 & Vellitor centropomus & SP-0049 & Colonial tunicate & Didemnidae sp. & 13-Apr-14 & Kitakoura & 2.0 & 9.9 & 2 & 2 & $1.5(2)$ & Yellow & 1 \\
\hline 29 & SPE-037 & Vellitor centropomus & SP-0051 & Sponge & Demospongiae sp. & 11-Mar-16 & Kotoura & 6.0 & 10.7 & 7 & 2 & $1.4(7)$ & Yellowish orange & 2 \\
\hline 30 & SPE-039 & Vellitor centropomus & SP-0053 & Colonial tunicate & Didemnidae sp. & 11-Mar-16 & Kotoura & 6.0 & 10.7 & 2 & 2 & $1.5(2)$ & Yellowish orange & 2 \\
\hline 31 & SPE-019 & Pseudoblennius marmoratus & SP-0033 & Sponge & Demospongiae sp. & 05-May-12 & Kotoura & $4.0-7.0$ & 9.7 & 10 & 10 & $1.6(10)$ & Orange & 3 \\
\hline 32 & SPE-025 & Pseudoblennius marmoratus & SP-0039 & Sponge & Demospongiae sp. & 24-Mar-13 & Kitakoura & 9.0 & 9.8 & 33 & 33 & $1.6(10)$ & Orange & 3 \\
\hline 33 & SPE-033 & Pseudoblennius marmoratus & SP-0047 & Sponge & Demospongiae sp. & 11-Feb-14 & Kitakoura & 1.0 & 10.2 & 16 & 6 & $1.5(7)$ & Orange & 1 \\
\hline 34 & SPE-038 & Pseudoblennius marmoratus & SP-0052 & Sponge & Demospongiae sp. & 11-Mar-16 & Kotoura & 2.0 & 10.7 & 14 & 1 & $1.6(7)$ & Orange & 1 \\
\hline 35 & SPE-005 & Not identified & SP-0002 & Colonial tunicate & Didemnidae sp. & 02-Apr-12 & Kotoura & $7.0-9.0$ & 9.2 & & 0 & $1.4(10)$ & Yellow & 0 \\
\hline 36 & SPE-007 & Not identified & SP-0008 & Colonial tunicate & Didemnidae sp. & 15-Apr-12 & Kotoura & $8.0-12.0$ & 9.4 & 29 & 0 & $1.4(10)$ & Orange & 0 \\
\hline 37 & SPE-009 & Not identified & SP-0014 & Colonial tunicate & Didemnidae sp. & 15-Apr-12 & Kotoura & $8.0-12.0$ & 9.4 & 89 & 0 & $1.4(10)$ & Yellow & 0 \\
\hline 38 & SPE-010 & Not identified & SP-0014 & Colonial tunicate & Didemnidae sp. & 15-Apr-12 & Kotoura & $8.0-12.0$ & 9.4 & 196 & 0 & $1.4(10)$ & Yellow & 0 \\
\hline 39 & SPE-012 & Not identified & SP-0014 & Colonial tunicate & Didemnidae sp. & 15-Apr-12 & Kotoura & $8.0-12.0$ & 9.4 & 44 & 0 & $1.5(10)$ & Yellow & 0 \\
\hline 40 & SPE-013 & Not identified & SP-0024 & Colonial tunicate & Didemnidae sp. & 02-May-12 & Kotoura & $6.0-9.0$ & 13.6 & 109 & 0 & ND & Yellow & 0 \\
\hline 41 & SPE-028 & Not identified & SP-0042 & Colonial tunicate & Didemnidae sp. & 26-Apr-13 & Kotoura & $8.0-11.0$ & 10.8 & & & Lost & & 0 \\
\hline 42 & SPE-036 & Not identified & SP-0050 & Sponge & Demospongiae sp. & 11-Mar-16 & Kotoura & 6.0 & 10.7 & 29 & 0 & $1.4(10)$ & Yellowish orange & 0 \\
\hline
\end{tabular}


Table S3 Results of genetic identification of parental species of egg masses deposited in solitary tunicates. Sampling date, locality, depth, water temperature (WT), number of eggs in hosts, number of hatched larvae, the average egg diameter, egg (yolk) coloration and number of young analyzed for genetic species identification are shown. $N D$, no data-

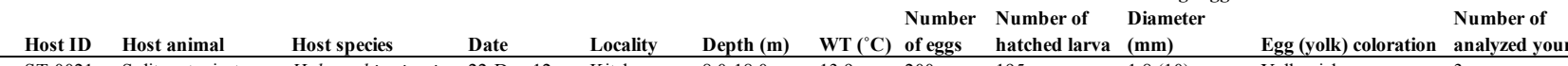

\begin{tabular}{|c|c|c|c|c|c|c|c|c|c|c|c|c|c|}
\hline Egg mass ID & Fish species & Host ID & Host animal & Host species & Date & Locality & Depth (m) & WT ( $\left.{ }^{\circ} \mathrm{C}\right)$ & of eggs & hatched larva & $(\mathrm{mm})$ & Egg (yolk) coloration & $\begin{array}{l}\text { analyzed young } \\
\end{array}$ \\
\hline & Pseudoblennius cottoides & $\begin{array}{l}\text { ST-0021 } \\
\end{array}$ & Solitary tunicate & Halocynthia ritteri & 22-Dec-12 & Kitakoura & $8.0-18.0$ & 13.9 & 200 & 195 & $1.8(10)$ & Yellowish orange & 3 \\
\hline
\end{tabular}

STE-005

STE-006

STE-007

STE-015

STE-018

STE-021

(10. STE-025

1 STE-026

$\begin{array}{ll}12 & \text { STE- } 028 \\ 13 & \text { STE-032 }\end{array}$

4 STE-034

15 STE- 035

16 STE- 036

17 STE- 038

$19 \quad$ STE-042

20 STE-043

21 STE-050

22 STE-051A

24 STE-052

25 STE-053

$\begin{array}{ll}26 & \text { STE- } 054 \\ 27 & \text { STE- } 055 \\ 28 & \text { STE }-056\end{array}$

28 STE- 056

$\begin{array}{lr}29 & \text { STE- } 057 \\ 30 & \text { STE-058 } \\ 3 & \text { STE-59 }\end{array}$

$31 \quad$ STE-059

$\begin{array}{ll}32 & \text { STE-063 } \\ 33 & \text { STE-064 }\end{array}$

34 STE-065

35 STE-066

36 STE-067A

37 STE-067B

39 STE-072

$\begin{array}{ll}40 & \text { STE- } 073 \\ 41 & \text { STE-074 }\end{array}$

$\begin{array}{ll}42 & \text { STE- } 075 \\ 43 & \text { STE-076 }\end{array}$

43 STE-076

$44 \quad$ STE-077

$\begin{array}{ll}45 & \text { STE- } 080 \\ 46 & \text { STE-081 }\end{array}$

$\begin{array}{ll}46 & \text { STE- } 081 \\ 47 & \text { STE- } 082\end{array}$

cottoides

Solitary tunicate

Halocynthia ritteri 25-Dec-12 Kitakoura 3.0-7.0

Pseudoblennius cottoides

Pseudoblennius cottoides

Psudoblennius cottoides

seudoblennius cottoides

Pseudoblennius cottoides

Pseudoblennius cottoides

Prestoblemins cotrides

Psendoblemius cottoides

doblennius cottoides

Pseudoblennius cottoides

$P_{\text {seudoblennius cottoides }}$

$P$ seudoblennius cottoides
seudoblennius cottoides

$P$ seudoblennius cottoides

Pseudoblennius cottoides

seudoblennius cottoides.

Pseudoblennius cottoides

seudoblennius cottoides

Pseudoblennius cottoides

Ps

Pseudoblennius contodes

us cottoides

$P$ seudoblennius cottoides

Peudoblennius cottoides

Pseudoblemius cottoides

cottoides

Pseudoblennius cottoides

Pseudoblennius cottoides.

Pseudoblennius cottoides

Pseudoblennius cottoides

seudoblennius cottoides

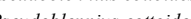

Psendoblemuius cottodes

Pseudoblennius cottoides

Pseudoblennius cottoides

Pseudoblennius cottoides

Pseudoblennius cottoides

Pseudoblennius cottoides

48 STE-083A

Pseudoblennius cottoides

itary tunicate

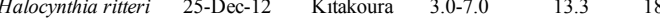

ST-0156 Solitary tunicate

ST-0191 Solitary tunicate

T-0198 Solitary tunicate

ST-0262 Solitary tunicate

$\begin{array}{llllll}\text { Halocynthia ritteri } & 25-\mathrm{Dec}-13 & \text { Kitakoura } & 0.5-3.9 & 13.3 & 210\end{array}$

$\begin{array}{llllll}\text { Halocynthia ritteri } & 25 \text {-Dec-13 } & \text { Kitakoura } & 0.5-3.9 & 13.3 & 66\end{array}$

Halocynhitartiten 25-Dec-13 Kitakoura 0.5-3.9

$\begin{array}{llllll}\text { Halocynthia ritteri } & 25-D e c-13 & \text { Kitakoura } & 0.5-3.9 & 13.3\end{array}$

Hether

ST-0301 Solitary tunicate

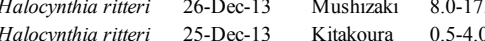

ST 0381 Solitiry tunicate

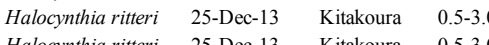

Solitary tunicate

ST-0397 Solitary tunicate

TT-0431 Solitary tunicate

ST-0545b Solitary tunicate

Halocynthia ritteri 25-Dec-13 Kitoura $0.5-3.3 .0$

\begin{tabular}{llllll} 
Halocynthin ritteri & 25 -Dec-13 & Kitakoura & $0.5-3.0$ & 14.1 & 255 \\
\hline
\end{tabular}

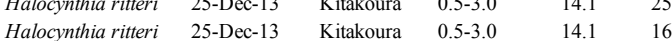

Halocynthia ritteri 25-Dec-13 Kitakoura 0.5-3.0

Solitary tunicate

Halocynthia ritteri 11-Feb-14 Kitakoura 0.5-3.9

ST-0631 Solitary tunicate

ST-0635 Solitary tunicate

ST-0635 Solitary tunicate

ST-0636 Solitary tunicate

T-0644 Solitary tunicate

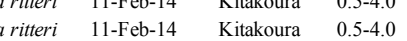

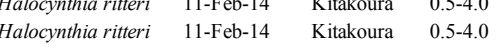

Halocynthia ritteri $\quad 11-\mathrm{Feb}-14 \quad$ Kitakoura $\quad 0.5-4.0$

Halocynthia ritteri $11-\mathrm{Feb}-14 \quad$ Kitakoura $\quad 0.5-4.0$

(t)

Halocynthiariteri 11-Feb-14 Kinkor 0.5.0

Halocynthia ritteri $\quad 11-\mathrm{Feb}-14 \quad$ Kitakoura $\quad 0.5-4.0$

ST-0654 Solitary tunicate

ST-0655 Solitary tunicate

ST-0658 Solitary tunicate

$\begin{array}{ll}\text { ST-0744 } & \text { Solitary tunicate } \\ \text { ST-0751 } & \text { Solitary tunicat }\end{array}$

ST-0754 Solitary tunicate

Halocynthia ritteri $\quad 11-\mathrm{Feb}-14 \quad$ Kitakoura $\quad 0.5-4.0$

$\begin{array}{llll}\text { Halocynthia ritteri } & 11-\mathrm{Feb}-14 & \text { Kitakoura } & 0.5-4.0 \\ \text { Halocy } & & 05-3.9\end{array}$

$\begin{array}{llll}\text { Halocynthia ritteri } & 06-M a r-14 & \text { Kitakoura } & 0.5-3.9 \\ \text { Halocynthia ritteri } & 06-M a r-14 & \text { Ka } & 0.5-3.9\end{array}$

\begin{tabular}{llll} 
Halocynthia ritteri & 06-Mar-14 & Kitakoura & $0.5-3.9$ \\
\hline
\end{tabular}

\begin{tabular}{cccc} 
Halocynthia ritteri & $06-\mathrm{Mar}-14$ & Kitakoura & $0.5-3.9$ \\
Halocynthi ritteri & $06-\mathrm{Mr}-14$ & Kitaoura & $05-3.9$ \\
\hline
\end{tabular}

ST-0857 Solitary tunicate

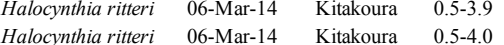

$\begin{array}{llll}\text { Halocynthia ritteri } & \text { 06-Mar-14 } & \text { Kitakoura } & 0.5-4.0 \\ \text { Kitakoura } & 0.5-4.0\end{array}$

$\begin{array}{llll}\text { Halocynthia ritteri } & 06-\mathrm{Mar}-14 & \text { Kitakoura } & 0.5-4.0 \\ \text { Helo } & & \end{array}$

Halocynthia ritteri $06-\mathrm{Mar}-14$ Kitakoura $0.5-4.0$

$\begin{array}{llll}\text { Halocynthia ritteri } & 06-\mathrm{Mar}-14 & \text { Kakoura } & 0.5-4.0 \\ \text { Kithoura } & 0.5-40\end{array}$

$\begin{array}{llll}\text { Halocynthia ritteri } & 06-\mathrm{Mar}-14 & \text { Kitakoura } & 0.5-4.0 \\ & & & \end{array}$

ST-0884 Solitary tunica

ST-0918 Solitary tunicate

ST-0922 Solitary tunicate

Solitiary tunicate

$\begin{array}{llll}\text { Halocynthia ritteri } & \text { 13-Apr-14 } & \text { Kitakoura } & 0.5-3.9 \\ \text { 13-Apr-14 } & \text { Kitakoura } & 0.5-3.9\end{array}$

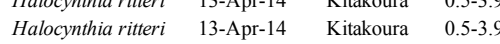

86
83
176
143
20
68
257
124
56
91
42
247
224
11
35
109
434
34
21
179
178
162
202
354
145
146
85
112
267
27
353
29
155
7
300
297
316
286
339
184
384
13
379
314
313
425

$1.9(10)$

Yellow

Yrange

$1.9(10) \quad$ Yellow

$\begin{array}{ll}1.9(10) & \text { Orange } \\ 1.8(10) & \text { Yellow }\end{array}$

$1.8(10)$

$1.9(10)$

8 (10) Yellow

Yellowish orange

$1.8(10) \quad$ Yellowish

$1.8(10) \quad$ Yellowish orange

$1.8(10) \quad$ Yellow

$1.9(10) \quad$ Yellow

$\begin{array}{ll}1.8(10) & \text { Orange } \\ 1.8(10) & \text { Yellow }\end{array}$

$1.9(10) \quad$ Yellow

$1.9(10) \quad$ Orange

$1.8(10) \quad$ Yellowish orange

$2.9(10) \quad$ Orange

Orange

.9(10) Yellow

1.9 (10) Yellowish orange

$1.9(10) \quad$ Yellowish orange

$1.8(10) \quad$ Orange
$1.9(10)$

1.9 (10) Yellow

$\begin{array}{ll}1.9(10) & \text { Reddish orange } \\ 1.9(10) & \text { Yellowish orang }\end{array}$

$1.9(10)$

$2.0(10)$

$1.8(10)$
$1.8(10)$

$1.8(10)$

$1.9(10)$

$1.9(10)$

$1.9(10)$

$2.0(10)$
$1.9(10)$
$1.9(10)$

$1.8(10)$

Yellow

Orange

Orange

Yrange

Yellowish orange

Orange
Orange

Yellowish orange

Yellowish orange
Yellowish orange

analyzed young

1
2
2
3




\begin{tabular}{|c|c|c|c|c|c|c|c|c|c|c|c|c|c|c|}
\hline 49 & STE-083B & Pseudoblennius cottoides & ST-0924 & Solitary tunicate & Halocynthia ritteri & 13-Apr-14 & Kitakoura & $0.5-3.9$ & 9.9 & 310 & 303 & $1.8(10)$ & Orange & 1 \\
\hline 50 & STE-086 & Pseudoblennius cottoides & ST-0940 & Solitary tunicate & Halocynthia ritteri & 13-Apr-14 & Kitakoura & $0.5-3.9$ & 9.9 & 400 & 316 & $1.9(10)$ & Orange & 1 \\
\hline 51 & STE-088 & Pseudoblennius cottoides & ST-0944 & Solitary tunicate & Halocynthia ritteri & 13-Apr-14 & Kitakoura & $0.5-3.9$ & 9.9 & 300 & 240 & $1.9(10)$ & Yellowish orange & 2 \\
\hline 52 & STE-090 & Pseudoblennius cottoides & ST-0986 & Solitary tunicate & Pyura sacciformis & 13-Apr-14 & Kitakoura & $0.5-3.9$ & 9.9 & 206 & 176 & $2.0(10)$ & Orange & 1 \\
\hline 53 & STE-003 & Pseudoblennius zonostigma & ST-0021 & Solitary tunicate & Halocynthia ritteri & 22-Dec-12 & Kitakoura & $8.0-18.0$ & 13.9 & 338 & 203 & $1.8(10)$ & Orange & 2 \\
\hline 54 & STE-009A & Pseudoblennius zonostigma & ST-0079 & Solitary tunicate & Halocynthia ritteri & 25-Dec-12 & Kitakoura & $3.0-7.0$ & 13.3 & 37 & 27 & $2.0(10)$ & Orange & 3 \\
\hline 55 & STE-009B & Pseudoblennius zonostigma & ST-0079 & Solitary tunicate & Halocynthia ritteri & 26-Dec-12 & Kitakoura & $3.0-7.0$ & 13.3 & 7 & 6 & $1.9(6)$ & Orange & 2 \\
\hline 56 & STE-011 & Pseudoblennius zonostigma & ST-0120 & Solitary tunicate & Halocynthia ritteri & 25-Dec-13 & Kitakoura & $0.5-3.9$ & 13.3 & 290 & 222 & $1.8(10)$ & Yellow & 1 \\
\hline 57 & STE-014 & Pseudoblennius zonostigma & ST-0149 & Solitary tunicate & Halocynthia ritteri & 25-Dec-13 & Kitakoura & $0.5-3.9$ & 13.3 & 163 & 135 & $1.7(10)$ & Yellowish orange & 2 \\
\hline 58 & STE-016A & Pseudoblennius zonostigma & ST-0172 & Solitary tunicate & Halocynthia ritteri & 25 -Dec-13 & Kitakoura & $0.5-3.9$ & 13.3 & 57 & & $1.7(10)$ & Orange & 1 \\
\hline 59 & STE-016B & Pseudoblennius zonostigma & ST-0172 & Solitary tunicate & Halocynthia ritteri & 25-Dec-13 & Kitakoura & $0.5-3.9$ & 13.3 & 83 & 81 & $1.8(10)$ & Yellow & 2 \\
\hline 60 & STE-017 & Pseudoblennius zonostigma & ST-0178 & Solitary tunicate & Halocynthia ritteri & 25-Dec-13 & Kitakoura & $0.5-3.9$ & 13.3 & 106 & 84 & $1.8(10)$ & Orange & 1 \\
\hline 61 & STE-019 & Pseudoblennius zonostigma & ST-0185 & Solitary tunicate & Halocynthia ritteri & 25-Dec-13 & Kitakoura & $0.5-3.9$ & 13.3 & 136 & 137 & $1.7(10)$ & Orange & 1 \\
\hline 62 & STE-020 & Pseudoblennius zonostigma & ST-0190 & Solitary tunicate & Halocynthia ritteri & 25-Dec-13 & Kitakoura & $0.5-3.9$ & 13.3 & 52 & 28 & $1.8(10)$ & Orange & 1 \\
\hline 63 & STE-027 & Pseudoblennius zonostigma & ST-0273 & Solitary tunicate & Halocynthia ritteri & 26-Dec-13 & Mushizaki & $8.0-17.8$ & 14.3 & 229 & 156 & $1.8(10)$ & Yellowish orange & 1 \\
\hline 64 & STE-030 & Pseudoblennius zonostigma & ST-0331 & Solitary tunicate & Halocynthia ritteri & 25-Dec-13 & Kitakoura & $0.5-3.0$ & 14.1 & 139 & 158 & $1.8(10)$ & Orange & 1 \\
\hline 65 & STE-049 & Pseudoblennius zonostigma & ST-0623 & Solitary tunicate & Halocynthia ritteri & 11-Feb-14 & Kitakoura & $0.5-4.0$ & 10.2 & 140 & 128 & $1.8(7)$ & Yellowish orange & 2 \\
\hline 66 & STE-002 & Pseudoblennius sp. "Kirin-anahaze" & ST-0000B & Solitary tunicate & Halocynthia ritteri & 13-Dec-11 & Tassha & 3.0 & 15.5 & 450 & 443 & $1.9(10)$ & Yellow & 3 \\
\hline 67 & STE-010 & Pseudoblennius sp. "Kirin-anahaze" & & Solitary tunicate & Halocynthia ritteri & & & & & & 525 & ND & & 3 \\
\hline 68 & STE-013 & Pseudoblennius sp. "Kirin-anahaze" & ST-0134 & Solitary tunicate & Halocynthia ritteri & 25-Dec-13 & Kitakoura & $0.5-3.9$ & 13.3 & 702 & 690 & $1.9(10)$ & Yellow & 3 \\
\hline 69 & STE-024 & Pseudoblennius sp. "Kirin-anahaze" & ST-0259 & Solitary tunicate & Halocynthia roretzi & 26-Dec-13 & Mushizaki & $8.0-17.8$ & 14.3 & 655 & 214 & $2.0(10)$ & Yellow & 3 \\
\hline 70 & STE-029 & Pseudoblennius sp. "Kirin-anahaze" & ST-0317 & Solitary tunicate & Halocynthia ritteri & 25-Dec-13 & Kitakoura & $0.5-4.0$ & 13.3 & 395 & 144 & $2.0(10)$ & Yellow & 2 \\
\hline 71 & STE-033 & Pseudoblennius sp. "Kirin-anahaze" & ST-0379 & Solitary tunicate & Halocynthia ritteri & 25 -Dec-13 & Kitakoura & $0.5-3.0$ & 14.1 & 1200 & 642 & $2.0(10)$ & Yellow & 2 \\
\hline 72 & STE-037 & Pseudoblennius sp. "Kirin-anahaze" & ST-0399 & Solitary tunicate & Halocynthia ritteri & 25-Dec-13 & Kitakoura & $0.5-3.0$ & 14.1 & 870 & 15 & $2.0(10)$ & Yellow & 2 \\
\hline 73 & STE-044 & Pseudoblennius sp. "Kirin-anahaze" & ST-0567 & Solitary tunicate & Halocynthia ritteri & 11-Feb-14 & Kitakoura & $0.5-3.9$ & 10.2 & 1000 & 913 & $2.0(10)$ & Yellow & 2 \\
\hline 74 & STE-046 & Pseudoblennius sp. "Kirin-anahaze" & ST-0576 & Solitary tunicate & Halocynthia ritteri & 11-Feb-14 & Kitakoura & $0.5-3.9$ & 10.2 & 680 & 624 & $2.0(10)$ & Yellow & 2 \\
\hline 75 & STE-023 & Pseudoblennius percoides & ST-0222 & Solitary tunicate & Pyura sacciformis & 25-Dec-13 & Kitakoura & $0.5-3.9$ & 13.3 & 147 & 125 & $1.9(10)$ & Yellowish green & 2 \\
\hline 76 & STE-031 & Pseudoblennius percoides & ST-0369 & Solitary tunicate & Halocynthia ritteri & 25-Dec-13 & Kitakoura & $0.5-3.0$ & 14.1 & 37 & 23 & $1.9(10)$ & Yellow & 1 \\
\hline 77 & STE-045 & Pseudoblennius percoides & ST-0574 & Solitary tunicate & Halocynthia ritteri & 11-Feb-14 & Kitakoura & $0.5-3.9$ & 10.2 & 121 & 121 & $1.8(10)$ & Yellowish orange & 2 \\
\hline 78 & STE-047 & Pseudoblennius percoides & ST-0588 & Solitary tunicate & Halocynthia ritteri & 11-Feb-14 & Kitakoura & $0.5-3.9$ & 10.2 & 161 & 106 & $1.9(10)$ & Orange & 2 \\
\hline 79 & STE-060 & Pseudoblennius percoides & ST-0728 & Solitary tunicate & Halocynthia ritteri & 06-Mar-14 & Kitakoura & $0.5-3.9$ & 8.8 & 89 & & $1.9(10)$ & Yellow & 2 \\
\hline 80 & STE-062 & Pseudoblennius percoides & ST-0735 & Solitary tunicate & Pyura sacciformis & 06-Mar-14 & Kitakoura & $0.5-3.9$ & 8.8 & & 107 & $1.9(10)$ & Yellowish green & 2 \\
\hline 81 & STE-068 & Pseudoblennius percoides & ST-0773 & Solitary tunicate & Halocynthia ritteri & 06-Mar-14 & Kitakoura & $0.5-3.9$ & 8.8 & 140 & 140 & $2.0(10)$ & Yellowish green & 2 \\
\hline 82 & STE-078 & Pseudoblennius percoides & ST-0910 & Solitary tunicate & Halocynthia ritteri & 06-Mar-14 & Kitakoura & $0.5-4.0$ & 8.8 & 80 & 80 & $2.0(10)$ & Yellowish green & 1 \\
\hline 83 & STE-048 & Furcina osimae & ST-0612 & Solitary tunicate & Pyura sacciformis & 11-Feb-14 & Kitakoura & $0.5-3.9$ & 10.2 & 73 & 72 & $1.6(10)$ & Reddish orange & 2 \\
\hline 84 & STE-069 & Furcina osimae & ST-0786 & Solitary tunicate & Pyura sacciformis & 06-Mar-14 & Kitakoura & $0.5-3.9$ & 8.8 & 75 & 75 & $1.6(10)$ & Red & 2 \\
\hline 85 & STE-070 & Furcina osimae & ST-0794 & Solitary tunicate & Pyura sacciformis & 06-Mar-14 & Kitakoura & $0.5-3.9$ & 8.8 & 83 & 83 & $1.7(10)$ & Red & 2 \\
\hline 86 & STE-001 & Furcina ishikawae & ST-0000A & Solitary tunicate & Halocynthia ritteri & 13-Dec-11 & Tassha & 2.0 & 15.5 & 35 & 31 & ND & Reddish orange & 2 \\
\hline 87 & STE-012 & Not identified & ST-0130 & Solitary tunicate & Halocynthia ritteri & 25-Dec-13 & Kitakoura & $0.5-3.9$ & 13.3 & 26 & 0 & Dead & White (dead) & 0 \\
\hline 88 & STE-039 & Not identified & ST-0435 & Solitary tunicate & Halocynthia ritteri & 25-Dec-13 & Kitakoura & $0.5-3.0$ & 14.1 & 250 & 0 & Dead & White (dead) & 0 \\
\hline 89 & STE-041 & Not identified & ST-0491 & Solitary tunicate & Halocynthia ritteri & 25-Dec-13 & Kitakoura & $0.5-3.0$ & 14.1 & 300 & 0 & Dead & White (dead) & 0 \\
\hline 90 & STE-061 & Aulichthys japonicas & ST-0731 & Solitary tunicate & Halocynthia ritteri & 06-Mar-14 & Kitakoura & $0.5-3.9$ & 8.8 & 58 & 48 & $2.6(10)$ & Orange & - \\
\hline 91 & STE-079 & Aulichthys japonicas & ST-0863 & Solitary tunicate & Halocynthia roretzi & 06-Mar-14 & Kitakoura & $0.5-4.0$ & 8.8 & & 208 & ND & Orange & - \\
\hline 92 & STE-084 & Aulichthys japonicas & ST-0938 & Solitary tunicate & Halocynthia ritteri & 13-Apr-14 & Kitakoura & $0.5-3.9$ & 9.9 & 64 & 69 & $2.5(10)$ & Orange & - \\
\hline 93 & STE- 085 & Aulichthys japonicas & ST-0939 & Solitary tunicate & Halocynthia ritteri & 13-Apr-14 & Kitakoura & $0.5-3.9$ & 9.9 & 110 & 81 & $2.6(10)$ & Orange & - \\
\hline 94 & STE-087 & Aulichthys japonicas & ST-0943 & Solitary tunicate & Pyura sacciformis & 13-Apr-14 & Kitakoura & $0.5-3.9$ & 9.9 & 95 & 133 & $2.6(10)$ & Orange & - \\
\hline 95 & STE-089A & Aulichthys japonicas & ST-0948 & Solitary tunicate & Halocynthia ritteri & 13-Apr-14 & Kitakoura & $0.5-3.9$ & 9.9 & 38 & 46 & $2.6(10)$ & Reddish orange & - \\
\hline 96 & STE-089B & Aulichthys japonicas & ST-0948 & Solitary tunicate & Halocynthia ritteri & 13-Apr-14 & Kitakoura & $0.5-3.9$ & 9.9 & 59 & 56 & $2.6(10)$ & Orange & - \\
\hline 97 & STE-091 & Aulichthys japonicas & ST-0987 & Solitary tunicate & Halocynthia ritteri & 13-Apr-14 & Kitakoura & $0.5-3.9$ & 9.9 & 61 & 49 & $2.7(10)$ & Orange & - \\
\hline 98 & STE-092 & Aulichthys japonicas & ST-0991 & Solitary tunicate & Pyura sacciformis & 13-Apr-14 & Kitakoura & $0.5-3.9$ & 9.9 & 94 & 106 & $2.7(10)$ & Reddish orange & - \\
\hline 99 & STE-093 & Aulichthys japonicas & ST-0992 & Solitary tunicate & Pyura sacciformis & 13-Apr-14 & Kitakoura & $0.5-3.9$ & 9.9 & 72 & 73 & $2.6(10)$ & Orange & . \\
\hline 100 & STE-094 & Aulichthys japonicas & ST-1021 & Solitary tunicate & Halocynthia ritteri & 13-Apr-14 & Kitakoura & $0.5-4.0$ & 9.9 & 71 & 75 & $2.6(10)$ & Orange & - \\
\hline 101 & STE-095 & Aulichthys japonicas & ST-1043 & Solitary tunicate & Pyura sacciformis & 13-Apr-14 & Kitakoura & $0.5-4.0$ & 9.9 & 70 & 0 & $2.6(10)$ & Orange & - \\
\hline 102 & STE-096 & Aulichthys japonicas & ST-1051 & Solitary tunicate & Halocynthia ritteri & 13-Apr-14 & Kitakoura & $0.5-4.0$ & 9.9 & 72 & 0 & $2.7(10)$ & Orange & - \\
\hline 103 & STE-097A & Aulichthys japonicas & ST-1086 & Solitary tunicate & Pyura sacciformis & 13-Apr-14 & Kitakoura & $0.5-4.0$ & 9.9 & 59 & 63 & $2.8(10)$ & Orange & - \\
\hline 104 & STE-097B & Aulichthys japonicas & ST-1086 & Solitary tunicate & Pyura sacciformis & 13-Apr-14 & Kitakoura & $0.5-4.0$ & 9.9 & 55 & 27 & $2.8(10)$ & Reddish orange & - \\
\hline 105 & STE-097C & Aulichthys japonicas & ST-1086 & Solitary tunicate & Pyura sacciformis & 13-Apr-14 & Kitakoura & $0.5-4.0$ & 9.9 & 68 & 54 & $2.8(10)$ & Orange & - \\
\hline 106 & STE-098 & Aulichthys japonicas & ST-1087 & Solitary tunicate & Halocynthia ritteri & 13-Apr-14 & Kitakoura & $0.5-4.0$ & 9.9 & 62 & 0 & $2.8(10)$ & Orange & - \\
\hline 107 & STE-099 & Aulichthys japonicas & ST-1091 & Solitary tunicate & Halocynthia ritteri & 13-Apr-14 & Kitakoura & $0.5-4.0$ & 9.9 & 59 & 33 & $2.7(10)$ & Orange & - \\
\hline 108 & STE-100 & Aulichthys japonicas & ST-1126 & Solitary tunicate & Halocynthia ritteri & 25-May-14 & Kitakoura & $0.5-3.9$ & 14.4 & 60 & 0 & $2.3(6)$ & Reddish & - \\
\hline 109 & STE-101 & Aulichthys japonicas & ST-1144 & Solitary tunicate & Pyura sacciformis & 25-May-14 & Kitakoura & $0.5-3.9$ & 14.4 & 59 & 0 & $2.3(7)$ & Orange & - \\
\hline
\end{tabular}




\section{Supporting information}

Figure S1 Maximum likelihood phylogeny of nine species of potentially ostracophilous sculpins, with Jordania zonope as an outgroup, as reconstructed by MEGA ver. 7.0.14. using 800 bp cytb sequences, with the settings of the Tamura Nei model and 1000 bootstrap replicates. Values at nodes are bootstrap percentages.

Figure S2 Maximum likelihood phylogeny of the potential parental species and 205 eggs from 113 egg masses as reconstructed by MEGA ver. 7.0.14. using 800 bp cytb sequences, with the settings of the Tamura Nei model and 1000 bootstrap replicates. Values at nodes are bootstrap percentages.

Figure S3 Maximum likelihood phylogeny of the potential parental species and 18 eggs from 14 egg masses as reconstructed by MEGA ver. 7.0.14., using 628 bp cytb sequences, with the settings of Tamura Nei model and 1000 bootstrap replicates. Values at nodes are bootstrap percentages.

Movie S1 Spawning behaviours of female Pseudoblennius cottoides in the aquarium. Six Halocynthia ritteri on wire-netting were placed in a $75 \times 45 \times 45 \mathrm{~cm}$ aquarium. Eggs were deposited in the atrium of a tunicate through the atrial siphon using extremely long ovipositors. Eggs were probably released into the atrium when the female opened her mouth. The female stayed still on the tunicate after spawning. She ejected her ovipositor $1 \mathrm{~min} 22 \mathrm{sec}$ and left the tunicate $2 \mathrm{~min} 34 \mathrm{sec}$ after the insert, respectively (not shown). This movie was filmed by H. S. on Feb. 7, 2015. Fish and tunicates were collected on the coast of Sado Island in the Sea of Japan. 
Movie S2 Failure of spawning by female Pseudoblennius cottoides in the aquarium. The atrial siphon of the tunicate closed before the sculpin female inserted her ovipositor. Settings were the same as in Movie S1. This movie was filmed by H. S. on Feb. 1, 2015.

Movie S3 Spawning behaviours of female Pseudoblennius marmoratus in the field. Eggs were deposited in the spongocoel of a sponge using short ovipositors. This movie was filmed by Tomonobu Uryu on Dec. 28, 2009 at Izu Oceanic Park, Izu Peninsula, Pacific coast of Japan. Water temperature was about $16^{\circ} \mathrm{C}$ and water depth was about $5 \mathrm{~m}$. 


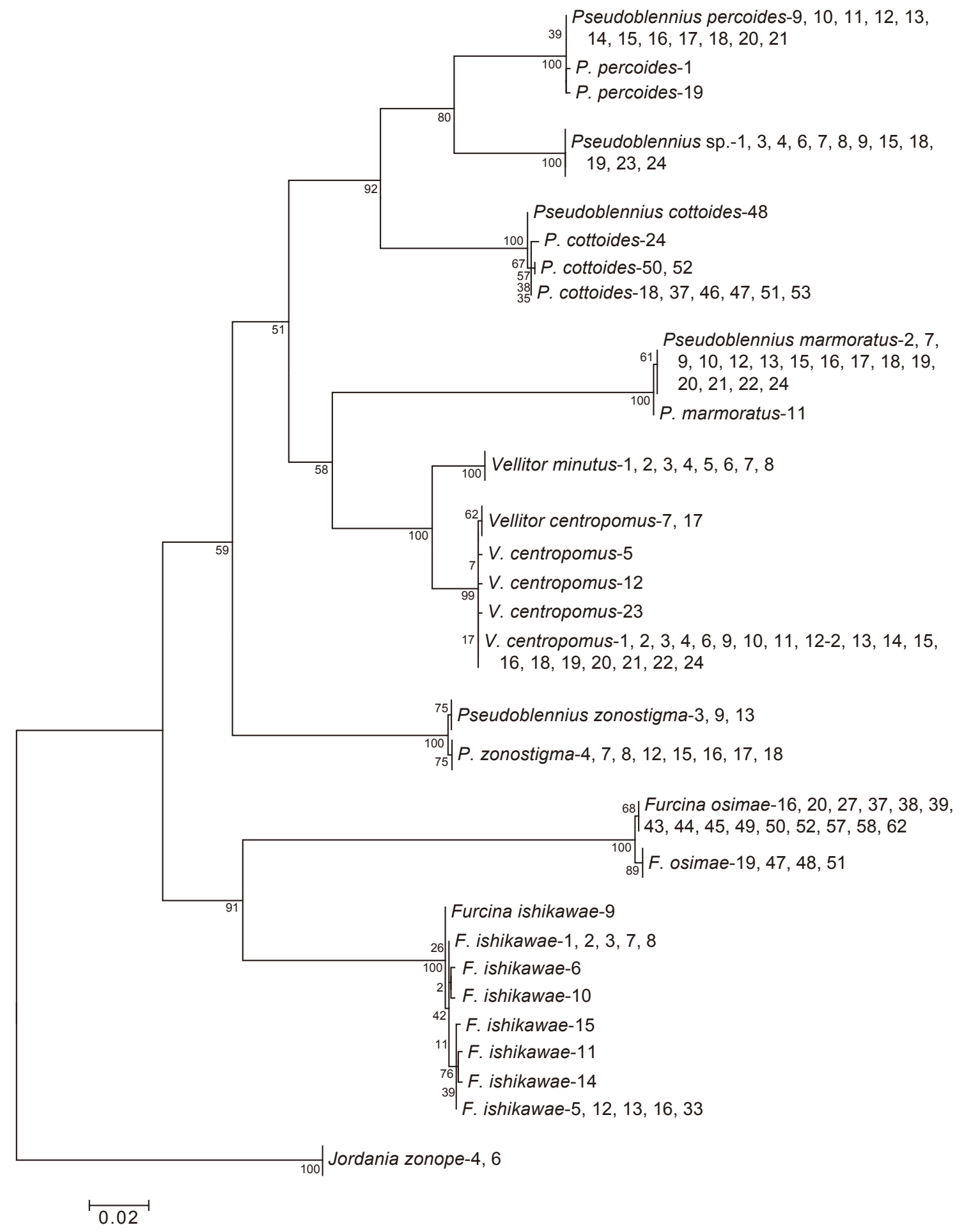

Figure S1 Maximum likelihood phylogeny of nine species of potentially ostracophilous sculpins, with Jordania zonope as an outgroup, as reconstructed by MEGA ver. 7.0.14. using 800 bp cytb sequences, with the settings of the Tamura Nei model and 1000 bootstrap replicates. Values at nodes are bootstrap percentages. 


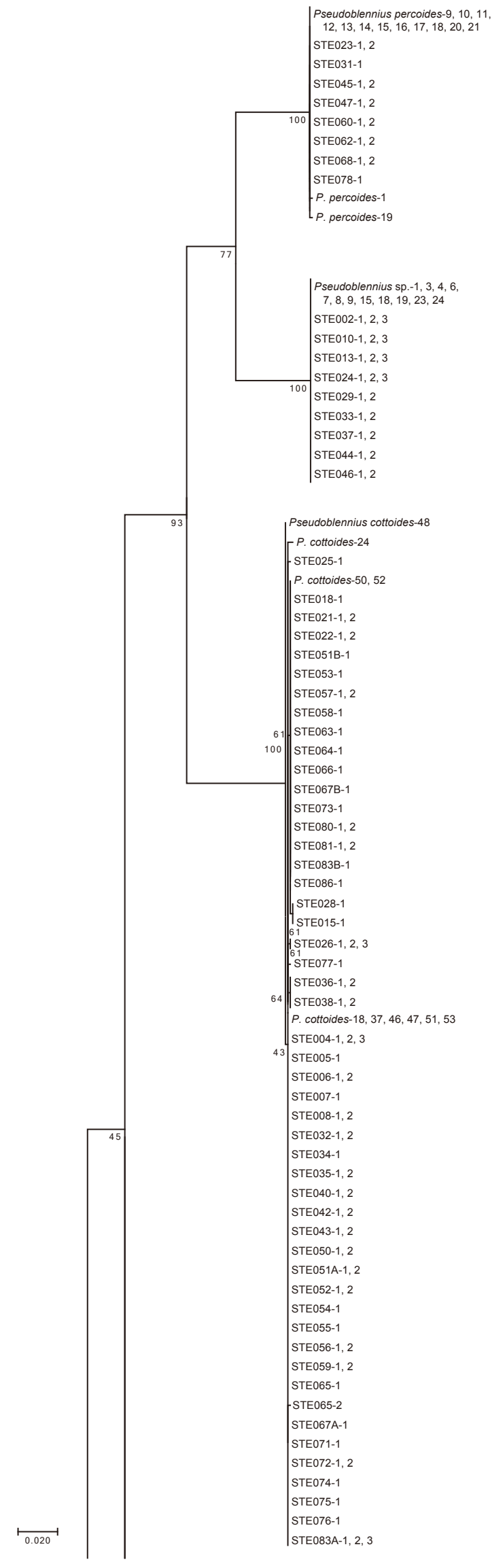




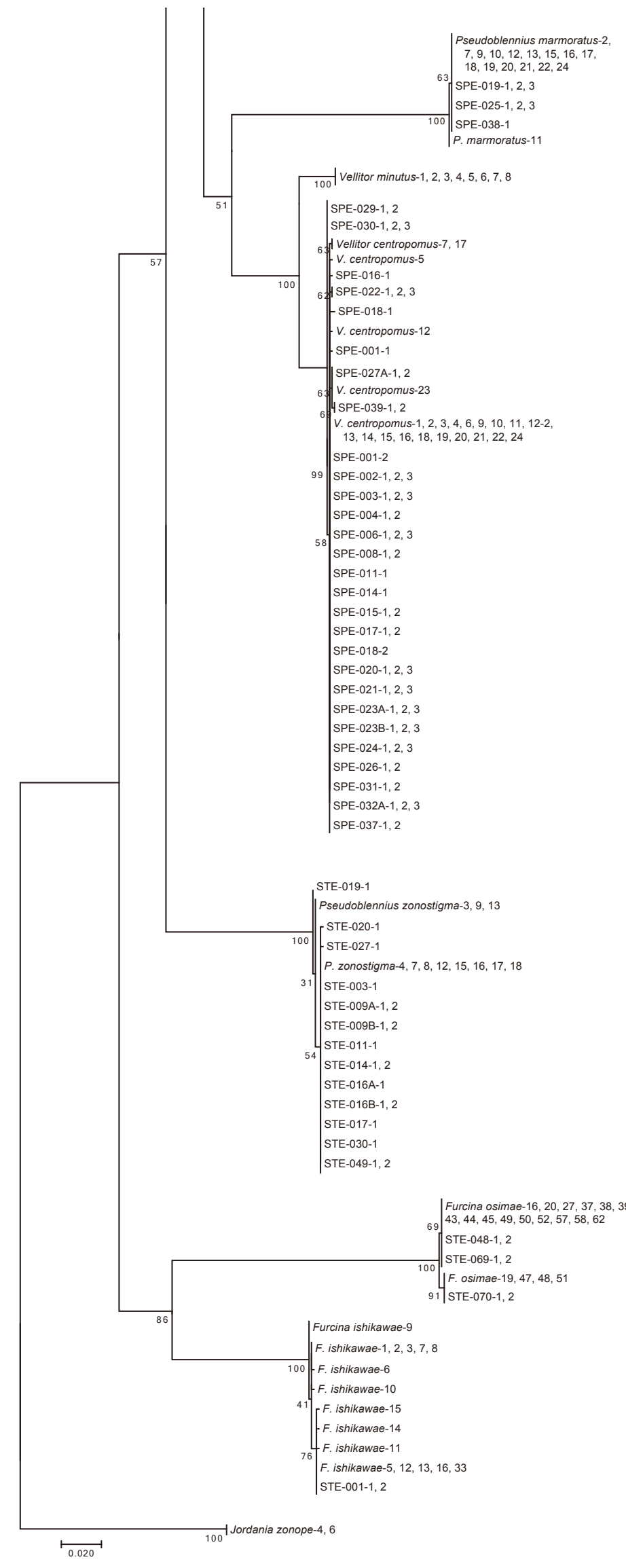

Figure S2 Maximum likelihood phylogeny of the potential parental species and 205 eggs from 113 egg masses as reconstructed by MEGA ver. 7.0.14. using $800 \mathrm{bp} c y t b$ sequences, with the settings of the Tamura Nei model and 1000 bootstrap replicates. Values at nodes are bootstrap percentages. 


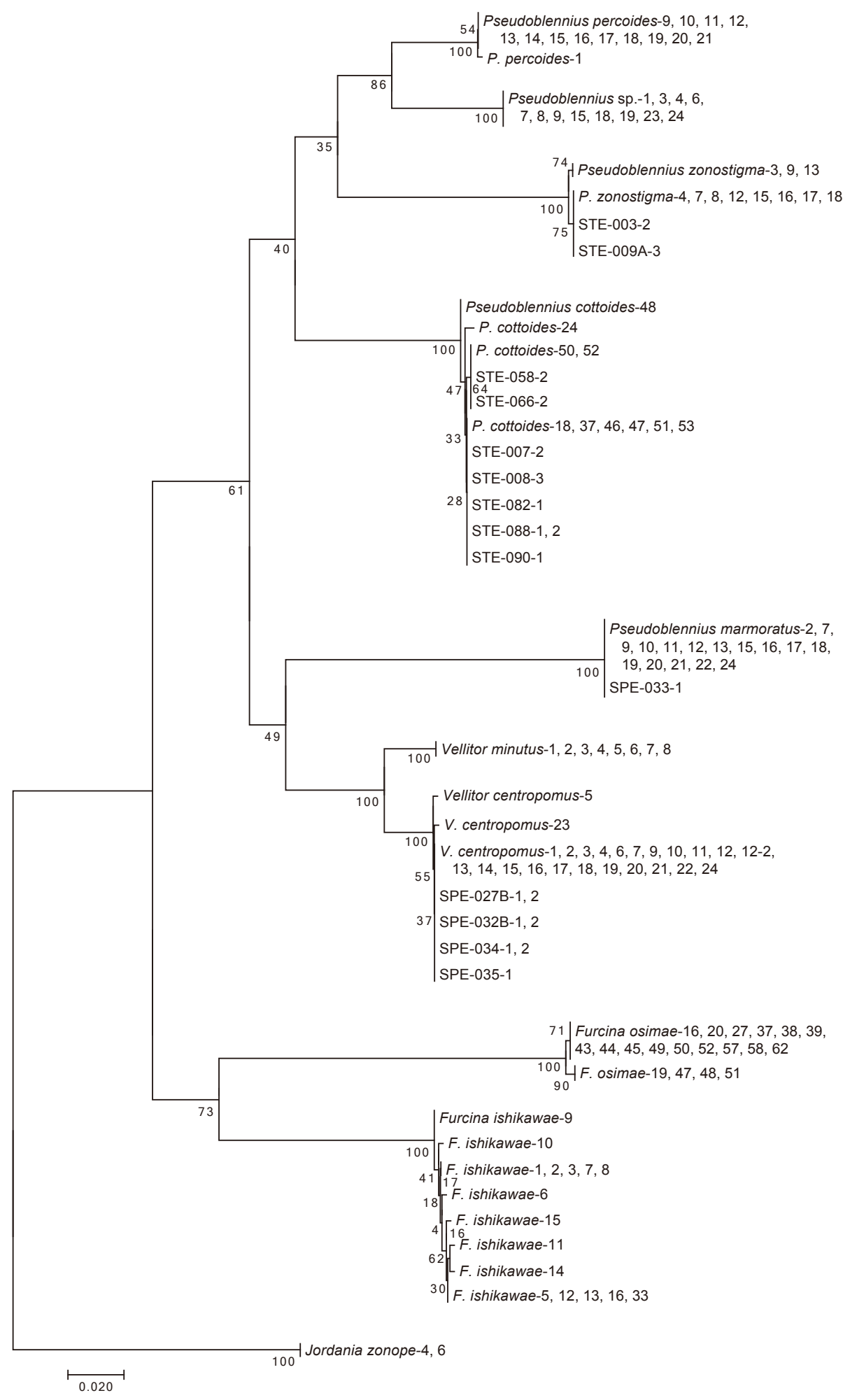

Figure S3 Maximum likelihood phylogeny of the potential parental species and 18 eggs from 14 egg masses as reconstructed by MEGA ver. 7.0.14., using $628 \mathrm{bp} c y t b$ sequences, with the settings of Tamura Nei model and 1000 bootstrap replicates. Values at nodes are bootstrap percentages. 


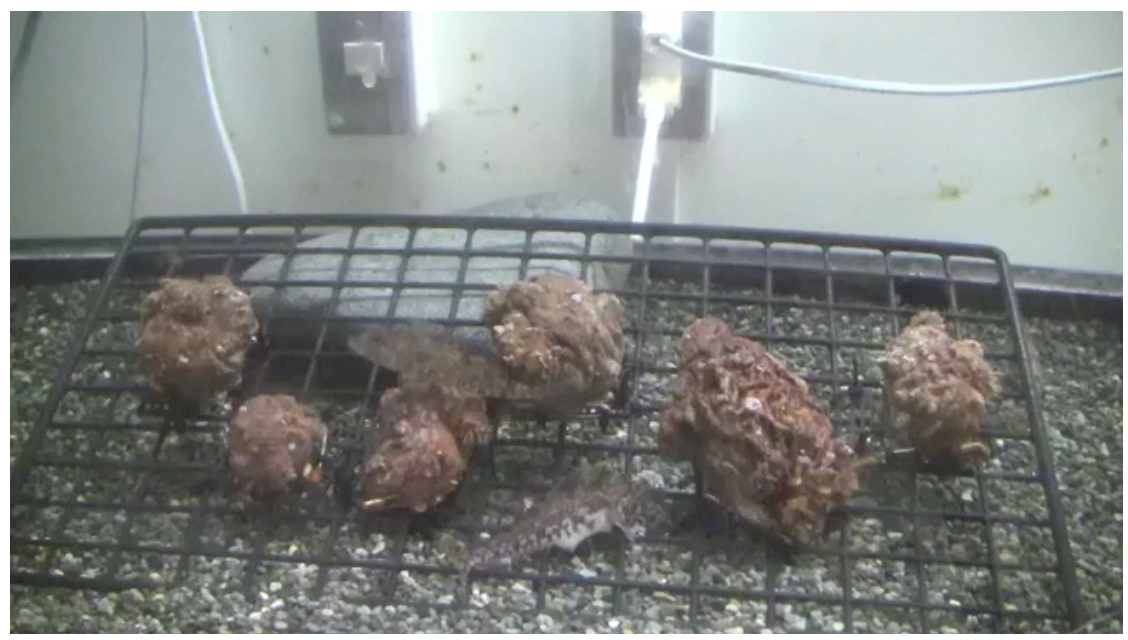

Movie S1 Spawning behaviours of female Pseudoblennius cottoides in the aquarium. Six

Halocynthia ritteri on wire-netting were placed in a $75 \times 45 \times 45 \mathrm{~cm}$ aquarium. Eggs were deposited in the atrium of a tunicate through the atrial siphon using extremely long ovipositors. Eggs were probably released into the atrium when the female opened her mouth. The female stayed still on the tunicate after spawning. She ejected her ovipositor $1 \mathrm{~min} 22 \mathrm{sec}$ and left the tunicate $2 \mathrm{~min} 34 \mathrm{sec}$ after the insert, respectively (not shown). This movie was filmed by H. S. on Feb. 7, 2015. Fish and tunicates were collected on the coast of Sado Island in the Sea of Japan.

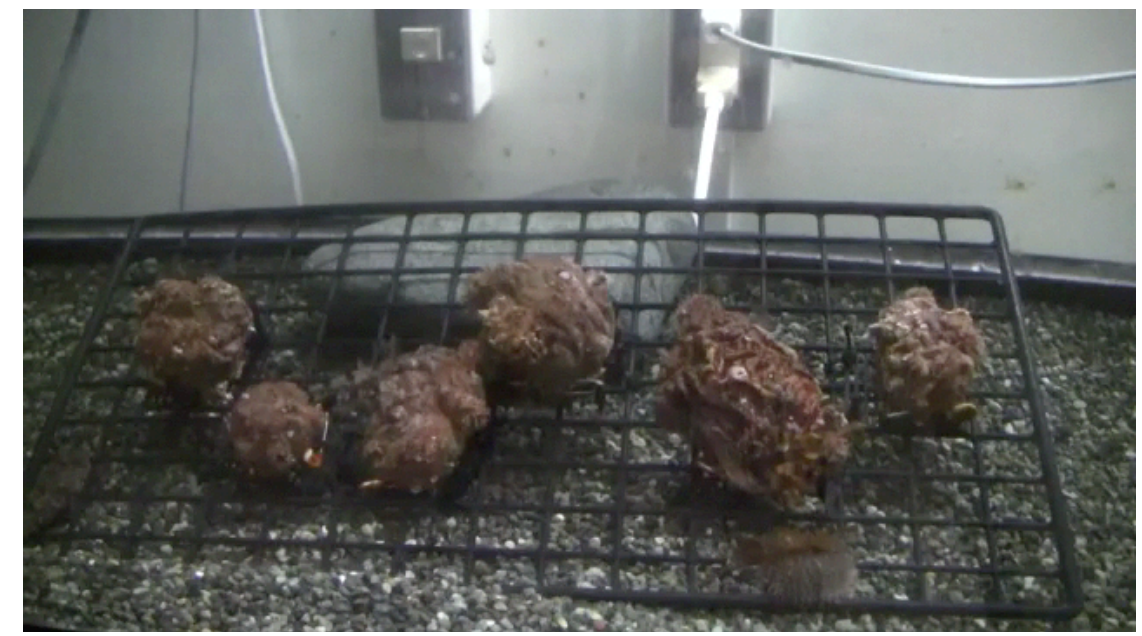

Movie S2 Failure of spawning by female Pseudoblennius cottoides in the aquarium. The atrial siphon of the tunicate closed before the sculpin female inserted her ovipositor. Settings were the same as in Movie S1. This movie was filmed by H. S. on Feb. 1, 2015. 


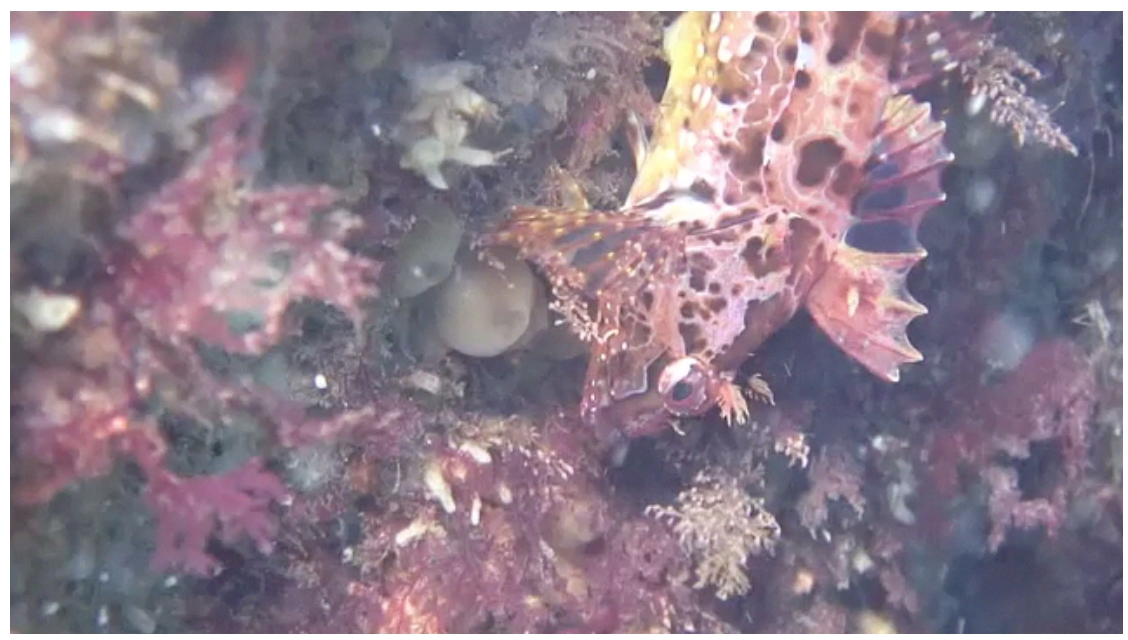

Movie S3 Spawning behaviours of female Pseudoblennius marmoratus in the field. Eggs were deposited in the spongocoel of a sponge using short ovipositors. This movie was filmed by Tomonobu Uryu on Dec. 28, 2009 at Izu Oceanic Park, Izu Peninsula, Pacific coast of Japan. Water temperature was about $16^{\circ} \mathrm{C}$ and water depth was about $5 \mathrm{~m}$. 